\title{
FILOSOFÍA DE LA PANDEMIA: UNA REVISIÓN CRÍTICA
}

\section{PHILOSOPHY OF THE PANDEMIC: A CRITICAL REVIEW}

\author{
LUIS DURÁN GUERRA \\ ludovicusdurandus@gmail.com \\ Universidad de Sevilla (España)
}

RECIBIDO: $08 / 07 / 2020$

ACEPTADO: 27/10/2020

Resumen: Este trabajo se divide en siete secciones. En las primeras seis se expone la posición sobre la Covid-19 de las principales celebridades del panorama filosófico internacional. El criterio seguido ha sido agrupar a los autores por nacionalidades o áreas culturales renunciando a toda crítica para intentar exponer objetivamente el punto de vista de cada filósofo. Por último, en la séptima sección, se lleva a cabo una revisión crítica de lo que los filósofos citados en la primera parte han escrito sobre la crisis del coronavirus. Desde este punto de vista, junto a mis propios comentarios críticos sobre el tema, se vuelven a retomar conjuntamente las tesis sostenidas en la primera parte de este trabajo con la intención de esbozar sus afinidades y contrastes.

Palabras clave: Biopolítica, coronavirus, crisis, estado de excepción, filosofía, pandemia.

Abstract: This paper is divided into seven sections. In the first six sections, I show the position on the Covid-19 pandemic of the main celebrities of the international philosophical scene. The criterion followed has been to group the authors by nationalities or cultural areas, renouncing all criticism in order to try to present objectively the point of view of each philosopher. Finally, in the seventh section, a critical review is made of what the philosophers cited in the first six parts have written about the coronavirus crisis. From this point of view, together with my own critical comments on the subject, the theses held by the authors are taken up again with the intention of outlining their affinities and contrasts.

Keywords: Biopolitics, coronavirus, crisis, state of exception, philosophy, pandemic. 


\section{Introducción}

Hegel decía que la lechuza de Minerva, el emblema tradicional de la filosofía, sólo levantaba su vuelo al atardecer, es decir, cuando ha pasado el tiempo necesario para poder pensar los acontecimientos. Sin embargo, como si entendieran el pensamiento más como un acto reflejo que como un ejercicio reflexivo, los filósofos contemporáneos de mayor relieve internacional no han podido esperar a que llegue la calma y se han precipitado a escribir en medio de la tormenta de la crisis del coronavirus. Sus aportaciones, por el momento, nos han llegado en forma de entrevistas y artículos de opinión de mayor o menor extensión que pueden leerse tanto en la prensa escrita como en los medios digitales, y son ya tan numerosos que es inevitable realizar una selección si no queremos hundirnos en un mar de especulaciones en medio de la desinformación general.

Foucault, al contrario de Hegel, pensaba que la filosofía debía ser algo así como una "ontología del presente”. La precipitación sería preferible a la espera que pospone la reflexión sobre la actualidad ad calendas graecas. Los filósofos contemporáneos son foucaultianos. Su apuro les ha llevado en ciertos casos a equivocarse, pero también a demostrar la viveza de un pensamiento que no claudica ante el mutismo ominoso de lo real. Y es que, parafraseando a Ortega y Gasset, la realidad tiene algo de pistoletazo que nos es disparado a quemarropa y callar, cuando se debe hablar, quizá no sea tanto un signo de prudencia sapiencial como de que no se tiene nada que decir.

En las páginas que siguen intentaré resumir la posición sobre la Covid-19 de las principales celebridades del panorama filosófico internacional. El criterio seguido ha sido agrupar a los autores por nacionalidades o áreas culturales renunciando a toda crítica para intentar exponer objetivamente el punto de vista de cada filósofo. 
Por último, en el apartado de conclusiones, trufadas con mis propios comentarios críticos, se vuelven a retomar conjuntamente las tesis sostenidas por los autores con la intención de esbozar sus afinidades y contrastes.

\section{Comunismo reinventado y miedo al otro: Žižek y Horvat}

El primer filósofo en reaccionar al coronavirus no podía ser otro que el mediático Slavoj Žižek. El 3 de febrero, el esloveno publicó en Russia Today un artículo titulado "Un claro elemento de histeria racista en el nuevo coronavirus”. Žižek, que ya ha publicado dos libros sobre el tema (2020a; 2020b), empezaba planteando preguntas provocativas: "¿dónde terminan los hechos y dónde comienza la ideología?”, “¿por qué hay tanta obsesión con esta [epidemia] cuando miles mueren diariamente por otras enfermedades infecciosas?” (2020, 8 de marzo).

Para Žižek, es obvio que estamos ante una "paranoia racista". A este respecto, quiero recordar cómo Donald Trump llamaba "virus chino" a la Covid-19. Pero la paranoia, el pánico colectivo, en realidad se deben a nuestro desconocimiento respecto al "mecanismo preciso” del virus. “¿Qué pasa si el virus muta de forma impredecible y desencadena una verdadera catástrofe global?”, pregunta el filósofo esloveno. Puede incluso que esta sospecha, que Žižek nos presenta como su propia "paranoia privada”, la sospecha de que el virus mute, sea la causa del pánico mostrado hasta ahora por las propias autoridades.

Lo que está claro para este autor es que los aislamientos y las cuarentenas no bastan para hacer frente al virus. Necesitamos "una solidaridad incondicional total y una respuesta coordinada globalmente", y cualquier otra cosa que no pase por una nueva forma de comunismo sólo puede conducirnos al caos y a la 
barbarie. O comunismo o barbarie, tal podría ser el resumen del diagnóstico de Žižek. Si no es así, Wuhan se convertirá en la ciudad del futuro, una ciudad que es claramente una distopía, una sociedad negativa, donde todo, incluso el amor, lo haremos virtualmente en casa a través de pantallas.

¿Podemos sacar alguna lección del confinamiento? Acaso sólo esta: poner entre paréntesis nuestra compulsión a la acción y retirarnos por un momento a ese espacio interior donde surgen las preguntas que nos sirven para repensar nuestra situación. En lugar de eso, concluye Žižek, lo único que nos preocupa (recordemos que escribe el 3 de febrero) es "cómo poner en cuarentena a los chinos".

El 27 de febrero, en un artículo titulado "Un golpe tipo 'Kill Bill' al capitalismo” (Žižek, 2020, 20 de marzo) el controvertido filósofo esloveno consideraba que lo que la crisis del coronavirus está poniendo de manifiesto es que la humanidad no puede seguir viviendo más como de costumbre y que es obvio que necesitamos "un cambio radical".

En este segundo texto, Žižek va más allá del primero y ve en el virus la oportunidad para superar los estados-nación y dar el golpe de gracia al capitalismo. Pero el comunismo que propone el filósofo como salida de la crisis no puede tener nada que ver con las formas históricas de comunismo que conocemos, sino con una nueva especie de comunismo "reinventado" que se base "en la confianza en las personas y en la ciencia". Lo triste del coronavirus, dice Žižek, es que la humanidad parece necesitar de la catástrofe "para que podamos repensar las características básicas de la sociedad en la que estamos viviendo".

El 16 de febrero, el filósofo croata Srećko Horvat publicaba en El País un artículo titulado "Lo más contagioso es el miedo" (2020, 16 de febrero). Según este autor, las pandemias son indicadores del funcionamiento de nuestras sociedades. Horvat denuncia los 
prejuicios y estereotipos sobre Oriente que se han disparado con el brote del coronavirus. "Parece como si todo lo que estaba reprimido volviese con un virus que ya está modelando la imaginación popular —y hasta apocalíptica — del año 2020". Si en el pesado fueron grupos minoritarios como los árabes o los judíos, los mendigos y las prostitutas, quienes fueron estigmatizados y segregados, en la actualidad, son los chinos los que sufren lo que Horvat llama los "horrores de la diversidad".

El filósofo extrae de estas premisas una conclusión ciertamente incómoda: "Evidentemente, el continente más oscuro no es China, la India o Congo, como en las fantasías estereotípicas sobre Oriente ahora reactivadas, sino el inconsciente humano. De momento, las reacciones al coronavirus han revelado menos sobre el microorganismo que sobre nosotros mismos" (Horvat, 2020, 16 de febrero).

Para Horvat, un virus no es sólo un virus, sino una forma ideológica de construir al "otro" en tanto enfermedad. El autor hace una referencia a varias obras literarias para ilustrar los "horrores de la diversidad" cuando se declara una epidemia, remitiéndonos a un famoso ensayo de la escritora norteamericana Susan Sontag que nos ilustra sobre la enfermedad como una metáfora que hay que deconstruir (Sontag, 1980).

Pero el coronavirus, concluye el croata, no es "chino", sino un "producto del capitalismo global”. En efecto: "Del mismo modo que, bajo los regímenes coloniales, las epidemias se extendían a través de las redes de caminos, ferrocarriles y canales de los imperios mundiales, el virus mortal no se está propagando por culpa de China (no es "chino"), sino porque nuestro mundo no ha estado nunca tan conectado como actualmente y porque todo se puede interrumpir, incluida la libre circulación de personas, excepto la circulación del capital” (Horvat, 2020, 16 de febrero). 
Según Horvat, el miedo al otro es más peligroso que el propio virus. De ahí que termine su texto previniéndonos contra los llamamientos fascistas al cierre de fronteras de quienes piensan que el capitalismo global puede pararlo todo menos la libre circulación de mercancías.

\section{Estado de excepción y biopolítica: Agamben y Esposito}

El 26 de febrero, uno de los filósofos contemporáneos más importantes, el italiano Giorgio Agamben, publicó un artículo bajo el desafortunado título "La invención de una epidemia” (Agamben, 2020, 26 de febrero). En esa fecha, el virus no se había extendido todavía en Italia de la forma en que conocemos, razón por la cual este filósofo, sin duda eminente, pudo considerar que las medidas de emergencia tomadas en su país eran "frenéticas, irracionales y completamente injustificadas”. Según Agamben, los gobiernos y los medios de comunicación conjuntamente estarían difundiendo un "clima de pánico". Dos serían los factores que explican esta situación.

El primero es la tendencia de los estados a utilizar el estado de excepción como "paradigma normal de gobierno". Como es sabido, el estado de excepción es un régimen que puede declarar el gobierno en situaciones especiales. El coronavirus sería una situación especial. Al haberse "agotado el terrorismo como causa de las situaciones excepcionales", sostiene Agamben (quien calificaba entonces el coronavirus como una "gripe normal"), se estaría "inventando" una epidemia para justificar las medidas excepcionales que se están tomando.

El segundo factor, no menos inquietante, sería el hecho de que nos estamos acostumbrando a vivir con miedo, o lo que es lo mismo, a necesitar "estados de pánico colectivos". La conclusión 
de Agamben no puede ser más desoladora: "Así, en un círculo vicioso perverso, la limitación de la libertad impuesta por los gobiernos es aceptada en nombre de un deseo de seguridad que ha sido inducido por los mismos gobiernos que ahora intervienen para satisfacerla” (2020, 26 de febrero).

En un segundo artículo, titulado "Contagio" y publicado el 11 de marzo, Giorgio Agamben volvía a reflexionar sobre el aislamiento decretado por su país para frenar la propagación del coronavirus. Agamben realiza una referencia erudita a la figura del untore, el untador, al que durante las plagas que asolaron a algunas ciudades italianas entre 1500 y 1600 , se instaba a denunciar "con el pretexto de llevar la peste a lo privado y a lo público". Con las medidas adoptadas por el gobierno, cada ciudadano, se convierte hoy en Italia, según Agamben, en un potencial untador que debe ser denunciado.

Pero a Agamben quizá le preocupa más el deterioro de las relaciones humanas que están provocando las medidas tomadas por su gobierno. El filósofo se muestra drástico: "Nuestro prójimo ha sido abolido”. La conclusión del texto se aproxima peligrosamente a la teoría de la conspiración. Las medidas habrían sido adoptadas por el mismo temor que se pretende provocar en la ciudadanía, creando así una situación buscada repetidamente por nuestros gobernantes: "que las universidades y las escuelas se cierren de una vez por todas y que las lecciones sólo se den en línea, que dejemos de reunirnos y hablar por razones políticas o culturales y sólo intercambiemos mensajes digitales, que en la medida de lo posible las máquinas sustituyan todo contacto - todo contagio - entre los seres humanos” (Agamben, 2020, 11 de marzo). ${ }^{1}$

\footnotetext{
${ }^{1}$ Dicho sea de paso, Nuccio Ordine no se encuentra lejos de este punto de vista. Este crítico literario y filósofo italiano de la lectura lanzaba una voz de alarma el 26 de marzo: "La auténtica lección es la que se da en las aulas, la experiencia humana que tenemos los profesores y los estudiantes juntos. Un ordenador nunca
} 
Tras las críticas recibidas de filósofos como Jean-Luc Nancy y Roberto Esposito, Agamben se vio obligado el 17 de marzo a precisar su posición en un tercer artículo titulado "Aclaraciones". Lo que pone de manifiesto el virus, en primer lugar, es que los italianos ya no creen en otra cosa que en la vida desnuda, un concepto clave de la filosofía de Agamben. Esto significa que la mera supervivencia es lo que importa en la presente situación. Ante el peligro de enfermar, todo aquello que importaba para nosotros, es sacrificado: "las condiciones normales de vida, las relaciones sociales, el trabajo, incluso las amistades, los afectos y las convicciones religiosas y políticas” (Agamben, 2020, 17 de marzo).

En segundo lugar, lo que la epidemia deja aparecer paradójicamente es la normalidad misma del estado de excepción al que se nos somete desde hace tiempo, tesis que Agamben ya había sostenido en su artículo del 26 de febrero. Pero una sociedad así, en estado de emergencia perpetua, jamás podrá considerarse una "sociedad libre”. En estas condiciones, concluye el filósofo, el lenguaje bélico no es extraño. Pero una guerra en la que el enemigo es invisible es una guerra absurda. Una guerra civil en la que el enemigo está dentro de nosotros mismos. Lo que preocupa, pues, de toda esta situación es no sólo o no tanto el presente, como lo que está por venir. Que los gobiernos, una vez pasada la emergencia sanitaria, busquen continuar los experimentos que no habían conseguido realizar antes. ${ }^{2}$

En un artículo del 28 de febrero, titulado "Cuidados a ultranza”, el también italiano Roberto Esposito no ve realmente en las decisiones excepcionales tomadas por los gobiernos un verdadero peligro para la democracia. Para este filósofo es innegable el despliegue de la biopolítica, un término ya utilizado por Foucault

cambiará la vida de un estudiante, pero la palabra de un profesor puede cambiar la vida de un muchacho” (Ordine, 2020, 26 de marzo).

${ }^{2}$ Agamben ya ha reunido sus artículos sobre la pandemia en un libro (2020). 
para referirse a la alianza entre política y biología que se remonta al menos a los siglos XVII y XVIII (Foucault, 2007).

Para Esposito, "todos los conflictos políticos actuales tienen en el centro la relación entre política y vida biológica” (2020, 12 de marzo). La vinculación de política y medicina deforma el perfil clásico de la política. Por consiguiente, el coronavirus sólo viene a confirmar la vigencia de la biopolítica. "Por un lado, se ha determinado un proceso de medicalización de una política que, aparentemente exenta de limitaciones ideológicas, se muestra cada vez más dedicada al "cuidado" de sus ciudadanos de los riesgos que, a menudo, ella misma enfatiza. Por otro lado, estamos presenciando una politización de la medicina, investida de tareas de control social que no le corresponden, lo que explica las evaluaciones heterogéneas de los virólogos sobre el alivio y la naturaleza del coronavirus” (Esposito, 2020, 12 de marzo).

Sin embargo, Esposito no cree que estemos asistiendo al nacimiento de un nuevo totalitarismo biopolítico. Las últimas palabras de su artículo no parecen dirigidas contra Nancy, sino contra Agamben: "Me parece que lo que sucede hoy en Italia, con la superposición caótica y un poco grotesca de prerrogativas estatales y regionales, tiene más el carácter de una descomposición de los poderes públicos que el de un dramático control totalitario" (Esposito, 2020, 12 de marzo).

Esposito ha seguido abundando sobre el tema en un artículo publicado también el 28 de febrero y vertido al español bajo el título de "Biopolítica y coronavirus". La tesis del autor no puede ser más contundente: con la aparición del coronavirus "estamos llegando al clímax de la relación directa entre la vida biológica y las intervenciones políticas" (Esposito, 2020, 24 de marzo). Este clímax se concreta en tres pasos diferenciados.

El primer paso tiene que ver con el cambio del objetivo político. El foco de atención no es ya el individuo, sino determinados 
sectores de la población. Esta población, considerada de riesgo, se vería afectada por "prácticas profilácticas", lo cual pondría en evidencia "el síndrome inmune real” del nuevo régimen biopolítico.

El segundo paso de esta biopolítica en curso sería lo que el filósofo italiano entiende como "doble proceso de medicalización de la política y politización de la medicina” (Esposito, 2020, 24 de marzo). Este paso ya fue apuntado en su anterior artículo, por lo que no me detendré mucho en comentarlo. Esposito viene a decirnos que los políticos hacen de médicos y los médicos de políticos. Vemos un Estado médico que se preocupa por la salud y una medicina política que no puede por menos que valorar "las consecuencias económicas y políticas que determinan las medidas sugeridas”.

El tercer paso vendría dado por "el cambio de los procedimientos democráticos ordinarios hacia disposiciones de emergencia” (Esposito, 2020, 24 de marzo). La idea es muy clara. Ante determinados estados de emergencia, como el que estamos viviendo, la democracia pasa a un segundo plano porque lo que importa es garantizar nuestra seguridad. Aunque Esposito parece discrepar con Agamben, creo que en este punto coinciden los dos filósofos italianos. Los estados de alarma son en realidad estados de excepción que suprimen los derechos y libertades de los individuos con el pretexto de preservar su seguridad.

Pero aquí los estados autoritarios gozarán siempre de una gran ventaja respecto a los estados democráticos. La conclusión de Esposito es al mismo tiempo una advertencia para todos nosotros: "Este impulso hacia el estado de excepción es aún más perturbador porque tiende a estandarizar los procedimientos políticos de los estados democráticos a los de los estados autoritarios como China. Con la advertencia de que, en este terreno, los estados autoritarios, 
por la propia naturaleza de su tipo de poder, siempre estarán por delante de los democráticos” (2020, 24 de marzo).

El 15 de marzo, Esposito publicaba un nuevo artículo traducido al español como "Democracia en tiempo de coronavirus" (2020, 30 de marzo). El pensador italiano no duda en calificar "lo que estamos viviendo" como un "estado de emergencia". Pero este estado no ha sido decretado por ninguna "voluntad soberana", sino por la necesidad objetiva de proteger a nuestras sociedades de algo que la está atacando desde dentro. Lo que está en juego es nada menos que la fortaleza del sistema inmunitario de la sociedad. Y ese sistema no es otro que el de nuestras instituciones. Si conseguimos preservarlas, nuestros líderes podrán debilitarse, pero las instituciones del país se mantendrán en pie.

Ahora bien, prosigue Esposito, la capacidad de nuestras instituciones para adaptarse a situaciones dramáticas como las que hoy vivimos, sólo puede darse bajo dos condiciones. La primera es que las instituciones extiendan su radio de influencia más allá del Estado soberano y no sucumban a la lógica siniestra del estado de excepción. Lo cual solo es posible si se cumple una segunda condición. Que los diversos movimientos que existen en la sociedad se institucionalicen y las instituciones, a su vez, se movilicen. La oposición, por consiguiente, entre instituciones y movimientos debe quedar abolida.

Esposito juega en su artículo con la metáfora del doble cuerpo del rey (Kantorowicz, 2012). Así como las monarquías tienen dos cuerpos, el físico y mortal, y el espiritual que garantiza la legitimidad de la institución; nuestra democracia tendría también un doble cuerpo, el físico, representado por los líderes políticos, y el espiritual, el cual corresponde a la permanencia de las instituciones democráticas. Lo que está en juego es, pues, la permanencia del cuerpo espiritual de la democracia, que no puede ser otro que nuestras instituciones. La única manera de evitar el 
estado de excepción permanente, tantas veces invocado, será apostando por "la pluralidad de liderazgo colectivo" frente a la tentación de exigir la “plenitud de poderes”.

\section{Excepción como regla y situación epidémica: Nancy y Badiou}

La primera réplica a Agamben vino de la mano del filósofo francés Jean-Luc Nancy mediante un breve artículo fechado el 27 de febrero y titulado “Excepción viral”. Respondiendo al primer texto de su amigo, Nancy no puede estar de acuerdo con que estemos ante una "gripe normal". Basta consultar los datos para cerciorarnos de que el coronavirus es capaz de una mortalidad mucho mayor que una gripe "normal”. Pero ésta no es la objeción más importante que el filósofo francés hace a su colega italiano.

Lo decisivo es que el estado de excepción, para Nancy, no es una simple medida gubernamental excesiva, sino la regla en un mundo cada vez más interconectado. Existe, en efecto, una especie de excepción, pero no sólo es viral, sino biológica, informática y cultural. Desde este punto de vista, sostiene este filósofo, "los gobiernos no son más que tristes ejecutores de la misma”, y criticarlos por llevar a cabo medidas excepcionales "es más una maniobra de distracción que una reflexión política” (Nancy, 2020, 28 de febrero).

Nancy recuerda, por último, no sin cierta ironía cariñosa, que si él hubiera seguido los consejos de su viejo amigo Agamben cuando necesitaba un trasplante de corazón, lo más seguro es que ya estuviera muerto. Es decir, por muy excepcional que sea el espíritu de un filósofo, y el de Agamben lo es, la verdad es que a veces éste también puede equivocarse. 
Pero Nancy no es el único filósofo francés en criticar el argumento del estado de excepción. En "Sobre la situación epidémica", un largo artículo publicado el 21 de marzo, Alain Badiou afirmaba tajantemente que la situación actual no tiene verdaderamente nada de excepcional. La prueba de ello es que existen otras epidemias, no menos mortíferas que el coronavirus, pero sobre todo porque conocemos un precedente del virus, el SARS 1, propagado por el mundo en la primavera de 2003. De hecho, el coronavirus se conoce también con el nombre de SARS 2. La epidemia no es, pues, como se ha dicho, algo nuevo e inédito, sino la segunda de este siglo cuya filiación resulta, por lo demás, identificable.

Las medidas de confinamiento tomadas por el gobierno francés, que Badiou aprueba sin matices, no representan tampoco ninguna novedad. Sin embargo, el filósofo marxista se muestra inquieto por las manifestaciones vertidas sobre el coronavirus en los medios. Es como si cierta gente pensara más en gozar con la tragedia que en combatirla eficazmente. ¿Qué tienen en común todas esas manifestaciones? Para Badiou, la respuesta es clara: "un curioso desprecio de la temible simplicidad y la ausencia de novedad, propias de la situación epidémica actual” (2020, 22 de marzo). Entre ellas se cuentan: las de los serviles ante los poderes, las de los místicos del ecologismo, las de los críticos del presidente, las de los "revolucionarios" utópicos, las de los pesimistas milenaristas o las de los nuevos despreciadores del "Yo primero", esa "regla de oro de la ideología contemporánea”.

Lejos de entregarse a estos afectos que nos retrotraen a la Edad Media, el filósofo francés se siente obligado a reunir algunas ideas simples, que él llama cartesianas. Lo primero que se debe hacer es definir claramente el problema. Una epidemia es una articulación compleja de determinaciones naturales y sociales. Hay que identificar el punto en que ambas determinaciones se entrecruzan. 
Y ese punto no es otro que los mercados de la provincia de Wuhan, "un medio popular muy denso y con una higiene rudimentaria".

Dicho esto, lo segundo que hay que saber es cómo ha transitado el virus del animal al hombre. Pero lo cierto es que aún no lo sabemos. Confiando en que la ciencia consiga averiguarlo, el autor de El ser y el acontecimiento tiene claro qué es lo que ha provocado la propagación global de la epidemia: "el acceso del capitalismo de Estado chino a un rango imperial, una presencia intensa y universal en el mercado mundial” (Badiou, 2020, 22 de marzo). Si al cruce naturaleza-sociedad que se observa en los mercados chinos, añadimos el factor del mercado mundial capitalista, con sus movimientos tan rápidos como incesantes, el resultado será la doble articulación de determinaciones naturales y sociales que caracteriza a la presente epidemia.

A continuación, el que fuera alcalde de Toulouse entre 1956 y 1961, se refiere a un hecho que demostraría la contradicción existente entre economía y política en el mundo contemporáneo. Pues una epidemia que es transversal, como Han y Gabriel se encargan también de recordarlo, se intenta frenar por parte de los estados-nacionales de una manera local. Desde este punto de vista, los gobiernos occidentales estarían más preocupados por respetar los mecanismos del Capital que de ajustar sus políticas para combatir el virus. ${ }^{3}$

En lo que respecta al lenguaje bélico y a la política estatista, Badiou tampoco ve en ello "nada sorprendente o paradójico". "Frente a una epidemia, este tipo de reflejos estatales es

\footnotetext{
${ }^{3}$ La misma falta de respuesta global ha sido denunciada por Edgar Morin desde unos presupuestos filosóficos totalmente distintos a los de Badiou. En un texto del 12 de marzo publicado por el diario Liberation escribía el filósofo de la complejidad: "De hecho, el virus está trayendo una nueva crisis planetaria a la crisis planetaria de la humanidad en la era de la globalización. Sin embargo, esta complejidad sigue siendo considerada y tratada en cuestiones y sectores separados en todas partes” (Morin, 2020, 13 de marzo).
} 
inevitable”, afirma el filósofo sin miramiento alguno. Sin el menor sentido crítico, el francés afirma que de aquí se sigue que la metáfora belicista utilizada por el presidente Macron es correcta. Se trata de una retórica lógicamente consecuente con la situación que estamos viviendo. Por consiguiente, "no es, de ningún modo, una puesta en escena, sino una necesidad impuesta por la difusión de un proceso mortal que entrecruza la naturaleza (de ahí el papel eminente de los científicos en este asunto) y el orden social (de ahí la intervención autoritaria del Estado que no puede ser de otra manera)" (Badiou, 2020, 22 de marzo).

A estas alturas, no debe resultar sorprendente la defensa de Badiou del gobierno de Macron. Así, frente a las acusaciones al gobierno francés de falta de previsión, este filósofo argumenta que nadie en Francia puede presumir de haber previsto nada, ni siquiera la izquierda, a la que acusa a su vez de haber participado en todo tipo de manifestaciones multitudinarias mientras la epidemia se estaba propagando en China. Si es así, ¿̇a qué está obligado el estado en la actual coyuntura? Badiou, que no oculta aquí sus ideas comunistas, no puede por menos que admitir que los intereses de la burguesía, fundamento último del estado, deben integrarse "con intereses más generales”.

¿Cabe esperar, entonces, alguna consecuencia política del coronavirus? Badiou se muestra escéptico. "Este tipo de situación (guerra mundial o epidemia mundial) es particularmente "neutra" en el plano político" (2020, 22 de marzo). El filósofo aduce aquí una prueba histórica para apoyar su tesis. Si exceptuamos los casos de Rusia y de China, en ningún pueblo occidental se ha producido una revolución como consecuencia de una guerra. Aunque Badiou no descarta que se pueda producir un debate sobre la propiedad privada cuando se supere la epidemia, la verdad es que es muy claro respecto a los sueños de un comunismo por venir tipo Žižek. Según el filósofo francés: "Es un sueño inconsistente y peligroso 
pensar que el capitalismo contemporáneo, que goza de la caída en todas partes de la hipótesis comunista, y que puede presentarse, entonces, como la única forma histórica posible para una sociedad de clases contemporánea, esté seriamente amenazado por lo que sucede actualmente” (Badiou, 2020, 22 de marzo).

La imposibilidad de un nuevo comunismo no impide, sin embargo, que "nosotros", dice el filósofo en referencia a su propio gremio, no debamos "trabajar mentalmente" durante este necesario confinamiento, "en el proyecto de nuevos lugares políticos y en el progreso transnacional de una tercera etapa del comunismo, después de aquella, brillante, de su invención, y de aquella otra, fuerte y compleja, pero finalmente derrotada, de su experimentación estatal” (Badiou, 2020, 22 de marzo).

A ese trabajo mental habría que añadir, concluye el autor de Lógica de los mundos, la crítica implacable de toda idea que presente la epidemia como algo políticamente innovador, así como de las pretendidas "redes sociales" como un lugar "de propagación de la parálisis mental bravucona, de rumores incontrolables, del descubrimiento de "novedades" antediluvianas, cuando no se trata de un oscurantismo fascistoide" (Badiou, 2020, 22 de marzo). En definitiva, que no debemos prestar crédito, especialmente durante el confinamiento, más que a las verdades controlables de la ciencia y a las medidas de una nueva política enfocada en la organización de las clases más vulnerables.

\section{Estado policial digital y orden mundial letal: Han y Gabriel}

La nueva estrella de la filosofía alemana, autor de auténticos best sellers, el surcoreano Byun-Chul Han no iba a ser menos que sus colegas y el 22 de marzo publicaba en el diario El País un largo artículo titulado "La emergencia viral y el mundo de mañana". Han 
comienza su artículo constatando el éxito de los países asiáticos frente a Occidente en la gestión de esta crisis sin precedentes. Europa está fracasando y la razón de su fracaso estriba en que, en lugar de "cooperar intensamente dentro de la Eurozona", se dedica insensatamente a cerrar fronteras. Pero la época de la soberanía de los estados-nación, según el surcoreano, ya ha pasado. La pregunta que plantea Han es la siguiente: ¿por qué Asia ha controlado mejor la pandemia?

La razón es de carácter cultural. Los asiáticos tienen una "mentalidad autoritaria” y colectivista que les permite aceptar sin conciencia crítica alguna las medidas tomadas por sus gobiernos. Entre esas medidas se encuentra una estricta "vigilancia digital" por la que se monitoriza la más mínima acción de su vida cotidiana. Con su gestión de los datos, el llamado Big Data, los asiáticos están protagonizando un cambio de paradigma del que Europa, afirma Han, “todavía no se ha enterado". La pandemia no sólo se combate con virólogos y epidemiólogos, sino sobre todo con informáticos y especialistas en macrodatos. He ahí lo que nos enseña Asia sobre el coronavirus.

Conceptos como "protección de datos" o "esfera privada" no existen en China. Lo que existe en el gigante asiático es una "biopolítica digital que acompaña a la psicopolítica digital que controla activamente a las personas" (Han, 2020, 22 de marzo). Se trata del control del cuerpo y de la mente soñada por los regímenes totalitarios. Soberano, por tanto, no es ya quien decide sobre el estado de excepción según la conocida fórmula de Carl Schmitt (2009), paradigma caduco al que se aferra Europa, sino "quien dispone de datos”. Una lección política que no deberíamos olvidar en la era de la información.

Al uso del Big Data y de la vigilancia digital por parte de los estados asiáticos (China, Corea del Sur, Japón, Taiwán, Hong Kong, Singapur), habría que añadir la diferencia entre Asia y 
Europa en lo que se refiere a las mascarillas protectoras. En efecto, mientras que entre los asiáticos está normalizado el uso de las mascarillas, en Europa casi nadie la lleva. La razón de esta diferencia también sería cultural. Escribe Han: "En Europa impera un individualismo que trae aparejada la costumbre de llevar la cara descubierta. Los únicos que van enmascarados son los criminales” (2020, 22 de marzo).

El filósofo surcoreano coincide con Agamben en que el estado de pánico desatado es desproporcionado, pero por razones diferentes. La primera razón tiene que ver con la globalización. Con ésta nos habíamos acostumbrado a vivir en un mundo sin fronteras, sin enemigos exteriores y, sobre todo, sin el temor a ser contagiados por algún agente patógeno. Han retoma aquí su tesis sobre el exceso de positividad que rige en las sociedades occidentales. Nos creíamos invulnerables porque habíamos eliminado de nuestras vidas el concepto de negatividad. Pero lo que ha venido con el virus es la negatividad misma de lo real. Según Han, "el pánico desmedido en vista del virus es una reacción inmunitaria social, e incluso global, al nuevo enemigo. La reacción inmunitaria es tan violenta porque hemos vivido durante mucho tiempo en una sociedad sin enemigos, en una sociedad de la positividad, y ahora el virus se percibe como un terror permanente" (2020, 22 de marzo).

La segunda razón por la que ha estallado el pánico se debe a la digitalización. La realidad virtual había eliminado a la realidad misma. La "apatía hacia la realidad" surge cuando nos sumergimos en un mundo que no ofrece resistencia alguna. Surge entonces un virus, que es real, y nos trae de vuelta a la realidad pura y dura que no podemos por menos que vivir como un despertar traumático. En lo que respecta al pánico de los mercados financieros, la razón hay que buscarla en el pánico que ya es inherente a ellos y no en el virus. "Lo que se refleja en el pánico del mercado financiero no es 
tanto el miedo al virus cuanto el miedo a sí mismo. El crash se podría haber producido también sin el virus. Quizá el virus solo sea el preludio de un crash mucho mayor" (Han, 2020, 22 de marzo).

Han no cree que la solución de la crisis pase por "un oscuro comunismo", tal y como sostiene Žižek. El virus no supondrá el final del capitalismo, tesis en la que Han coincide con Badiou. Antes bien, dado su éxito, lo que puede imponerse en Occidente es un estado policial digital como el chino. Ante esta perspectiva, al filósofo surcoreano afincado en Alemania, no le queda más que formular un deseo, lejos de toda especulación: "Ojalá que tras la conmoción que ha causado este virus no llegue a Europa un régimen policial digital como el chino. Si llegara a suceder eso, como teme Giorgio Agamben, el estado de excepción pasaría a ser la situación normal. Entonces el virus habría logrado lo que ni siquiera el terrorismo islámico consiguió del todo” (Han, 2020, 22 de marzo).

La conclusión de Han no puede ser más tajante. Del virus no cabe esperar ninguna revolución. El virus nos aísla y nos deja sumidos en la impotencia política. Sólo una revolución humana, racional, en modo alguno viral, podrá "repensar y restringir radicalmente el capitalismo destructivo, y también nuestra ilimitada y destructiva movilidad, para salvarnos a nosotros, para salvar el clima y nuestro bello planeta” (Han, 2020, 22 de marzo).

La otra estrella del firmamento filosófico alemán, el joven profesor Markus Gabriel, publicaba el 25 de marzo un texto en $E l$ País cuyo título es ya todo un manifiesto: "El orden mundial previo al virus era letal”. Gabriel nos recuerda la etimología de la palabra "pandemia" para advertirnos que no estamos ante "una enfermedad infecciosa cualquiera". Si pandemia significa "todo el pueblo", todos y cada uno de nosotros estamos afectados por el virus. La consecuencia lógica de esta situación es la falta de sentido del confinamiento de la población dentro de las fronteras nacionales. 
Gabriel coincide aquí con Han en el diagnóstico sobre la ineficacia del cierre de fronteras para evitar el contagio.

Según Gabriel, los virus plantean un problema metafísico. ¿Son realmente seres vivos? No lo sabemos, como no sabremos, afirma provocativamente el filósofo, si el coronavirus es en realidad "una respuesta inmune del planeta a la insolencia del ser humano, que destruye infinitos seres vivos por codicia” (Gabriel, 2020, 25 de marzo). Pero lo que está claro, para el autor de Por qué no existe el mundo, es el error en el que se basa la ideología del siglo XXI, la ideología del progreso científico y tecnológico. "El coronavirus pone de manifiesto las debilidades sistémicas de la ideología dominante del siglo XXI. Una de ellas es la creencia errónea de que el progreso científico y tecnológico por sí solo puede impulsar el progreso humano y moral” (Gabriel, 2020, 25 de marzo). Sin progreso moral, no pude haber ningún tipo de progreso.

La verdad que la pandemia descubre no es nueva. "Todos vamos en el mismo barco". Como resultado de la globalización, el mismo siglo XXI es el resultado de una pandemia que demanda "una Ilustración global totalmente nueva", no un comunismo reinventando, como sostiene Žižek, sino más bien lo que otra celebridad filosófica alemana, Peter Sloterdijk, llama un "coinmunismo", ${ }^{4}$ un estado de inmunidad planetaria que nos vacune, añade Gabriel, contra todo lo que nos separa, sean culturas nacionales, razas, grupos de edad o clases sociales.

Gabriel nos advierte que, una vez superado el virus, no podemos seguir actuando como antes. De lo contrario, profetiza el filósofo, vendrán crisis más graves, virus cuya propagación no podremos impedir: la guerra económica, el racismo y el nacionalismo, el cambio climático, etc. Si algo nos enseña esta experiencia es que el orden mundial previo a la pandemia no era normal, sino letal. Tras

\footnotetext{
${ }^{4}$ Véase sobre los sistemas inmunitarios la soberbia trilogía de Sloterdijk (2003; 2004; y 2006).
} 
una serie de preguntas retóricas que denuncian la letalidad de dicho orden, Gabriel insiste en la tesis de la necesidad de un pensamiento ilustrado para cambiar el sistema: "Necesitamos una nueva Ilustración, todo el mundo debe recibir una educación ética para que reconozcamos el enorme peligro que supone seguir a ciegas a la ciencia y a la técnica” (2020, 25 de marzo).

El filósofo alemán carece de contemplaciones con el capitalismo global. "Tenemos que reconocer que la cadena infecciosa del capitalismo global destruye nuestra naturaleza y atonta a los ciudadanos de los Estados nacionales para que nos convirtamos en turistas profesionales y en consumidores de bienes cuya producción causará a la larga más muertes que todos los virus juntos” (Gabriel, 2020, 25 de marzo). Gabriel concluye su texto subrayando que el conocimiento médico y virológico no son suficientes para hallar una salida de la "globalización suicida" del orden mundial previo al virus. Es imprescindible la "conciencia filosófica", una "pandemia metafísica" que nos haga despertar y comprender de una vez por todas la unidad de la humanidad bajo el techo común de un cielo del que nunca podremos evadirnos.

\section{Fracaso del mercado y fin del neoliberalismo: Chomsky y Gray}

El 17 de marzo, la revista italiana Il Manifesto publicaba una entrevista realizada al célebre lingüista estadounidense Noam Chomsky. En esta primera intervención, Chomsky aprovecha la situación para cargar de nuevo contra el neoliberalismo. El filósofo y politólogo, consternado por la gestión que está haciendo su país de la crisis, denuncia que "el asalto neoliberal ha dejado a los hospitales sin preparación" y deja claro que el coronavirus es un enésimo ejemplo del fracaso del mercado, "al igual que lo es la amenaza de una catástrofe ambiental” (2020, 17 de marzo). 
Pero Chomsky se ha explayado más sobre la crisis en una entrevista concedida al filósofo croata Horvat y realizada por videoconferencia (2020, 28 de marzo). El norteamericano recuerda su primer ensayo sobre la guerra civil española, cuando apenas tenía diez años, advirtiéndonos sobre la semejanza entre la Europa de los años 30 y nuestra propia época. Según Chomsky, hoy existen dos peligros más graves que el coronavirus: la amenaza de una guerra nuclear y el calentamiento global. Nunca hemos estado más cerca de la extinción total, afirma el lingüista con acento apocalíptico. A los dos peligros señalados, agravados desde que Trump fuese electo, el lingüista añade el deterioro de la democracia pues, aunque no parezca venir al caso, la democracia es nuestra única esperanza para superar una crisis que Chomsky describe como una crisis civilizatoria devastadora. En un tono pesimista, el autor de Estados fallidos se pregunta finalmente "si esta especie es siquiera viable".

Preguntado por el sentido del lenguaje bélico utilizado para enfrentar el coronavirus, el estadounidense piensa que no es una exageración si se tiene en cuenta la movilización que se requiere para hacer frente a este tipo de crisis. Pero Chomsky insiste en este punto, al igual que Gabriel, que el coronavirus es solo una pequeña fracción de una crisis mayor que está por venir. La pregunta que se desprende de su intervención es, por tanto, la siguiente: “¿Queremos el tipo de mundo que conduce a esto?” Según este autor, deberíamos pensar sobre los orígenes de la crisis, los cuales no son otros que los problemas socioeconómicos derivados del salvaje mercado neoliberal, un mercado que no ha sabido prevenir la pandemia por no resultarle rentable económicamente. Para el autor de Reflexiones sobre el lenguaje, vivimos bajo una ideología, la ideología neoliberal para la que el gobierno es el problema. En definitiva, Chomsky está convencido de que la crisis "supone un fracaso colosal del mercado, que apunta a problemas 
fundamentales de orden social y económico, empeorados por la plaga neoliberal” (2020, 28 de marzo), una crítica que también hace Ordine, para quien "la política neoliberal ha descuidado los pilares de la dignidad humana”.

¿Qué mundo nos espera si superamos la crisis? Ante esta pregunta, el lingüista norteamericano cree que no hay más que dos opciones. La primera es la instalación de Estados altamente autoritarios compatibles con el neoliberalismo; la segunda pasa por una reconstrucción radical de la sociedad que se preocupe más por las necesidades humanas que por el beneficio privado. En todo caso, lo que esta crisis pone de manifiesto son las profundas características disfuncionales de un sistema que debe responder de forma inmediata a la amenaza de la guerra nuclear y del cambio climático.

Por último, Horvat le pregunta a Chomsky sobre el futuro de la resistencia en estos tiempos de distanciamiento social. El intelectual norteamericano responde que en los últimos años se ha producido, sobre todo entre los jóvenes, una especie de aislamiento social auto inducido que es muy dañino. Chomsky se refiere al mal uso de las redes sociales, pero sostiene que en la actual situación de aislamiento social real debemos recrear los lazos sociales y promover con ayuda de las nuevas herramientas digitales organizaciones que sean eficaces y operativas. Pero la comunicación cara a cara es esencial para la humanidad y, por un tiempo, parece que se nos va a privar de ella. A la espera de recuperarla, nos aconseja el venerable pensador, debemos buscar sin desesperar otras formas de interactuación, pues el hombre ha superado en el pasado situaciones peores.

"La crisis por la que estamos pasando es un punto de inflexión en la historia” (Gray, 2020, 12 de abril). Así comienza un extenso artículo del prestigioso filósofo inglés John Gray publicado en $E l$ País el 12 de abril y titulado "Adiós a la globalización, comienza 
un mundo nuevo". Gray cree que la crisis del coronavirus pondrá fin al sistema económico liberal tal y como lo hemos conocido hasta ahora. Aunque afirma que "nuestro sistema político sobrevivirá intacto", el filósofo inglés está convencido de que vamos a asistir a un resurgir de los Estados nacionales. Al contrario de muchos de sus colegas, este autor no cree que la salida de la crisis pase por una mayor cooperación internacional, idea que le parece deudora de una suerte de "pensamiento mágico". Lo que veremos será un mayor control de la economía por parte de los Estados, los cuales asumirán en el futuro mayores funciones protectoras.

A este respecto, el autor de Perros de paja realiza una crítica de la Unión Europea por no haber sabido cumplir con la función protectora que se le debe exigir a cualquier Estado. Las reflexiones de Gray tienen un claro sabor histórico y geopolítico. Para este crítico de la idea de progreso: "Si la Unión Europea sobrevive, puede que se parezca al Sacro Imperio Romano en sus años finales, un fantasma que subsiste durante generaciones mientras el poder se ejerce en otro lugar” (Gray, 2020, 12 de abril). ¿En qué lugares se ejercerá el poder tras la crisis de la Covid-19? El politólogo británico apunta algunas ideas interesantes: Asia y Rusia avanzan, Oriente Medio y Occidente retroceden. Irán y Arabia Saudí, rehenes del petróleo, se están viendo perjudicadas por el cierre mundial. En cambio, países como Taiwán, Corea del Sur y Singapur se adaptarán posiblemente mejor que ningún otro a la desglobalización, mientras que, con su ayuda a Italia, China parece ocupar el lugar que le correspondería a la Unión Europea. En lo que respecta a esta última, Gray parece indicar su desventaja con el Reino Unido a la hora de implementar unas medidas que, si esta situación de crisis se prolonga, exigirán "una socialización de la economía aún mayor”. 
No es de extrañar, tras semejante profesión de fe euroescéptica, que Gray se refiera a la dependencia de Europa del gas ruso como una prueba de la creciente influencia del coloso eslavo sobre el viejo continente. En lo que se refiere a Estados Unidos, el autor de Misa negra compara su gestión de la crisis con la británica y lanza una pregunta inquietante: “¿Qué pasará si el presidente sale de esta catástrofe con el apoyo de una mayoría de estadounidenses?” Pero con independencia de que Trump conserve o no el poder, lo que es seguro es que "la posición de Estados Unidos en el mundo ha cambiado de manera irreversible”. A esta altura de su artículo, el filósofo británico se siente ya en condiciones de aventurar un pronóstico histórico de envergadura: "Lo que se está desmoronando a toda velocidad no es solo la hiperglobalización de las últimas décadas, sino el orden mundial implantado tras el final de la II Guerra Mundial. El virus ha roto un equilibrio imaginario y ha acelerado un proceso de desintegración en marcha desde hace años” (Gray, 2020, 12 de abril).

¿Constituyen las pandemias una excepción en el curso de la historia? Gray no lo cree así, pues a su juicio esta idea se basa en una creencia tenida por indiscutible: "la creencia de que los seres humanos ya no formamos parte del mundo natural y podemos crear un ecosistema autónomo, separado de la biosfera” (2020, 12 de abril). Pero lo que la Covid-19 demuestra es la falsedad de este prejuicio filosófico. Lo que es seguro es que tendremos que cambiar nuestro modo de vida si queremos ser en el futuro menos vulnerables. El cambio ya es perceptible. "La textura de la vida cotidiana ya ha cambiado. En todas partes existe un sentimiento de fragilidad. [...] La belleza no humana y una feroz lucha por la vida han brotado rápidamente en las urbes vaciadas por el virus” (Gray, 2020, 12 de abril), escribe este autor conocido por su crítica a la humanidad como una especie que destruye su medio ambiente natural. 
Gray prosigue su texto con algunas reflexiones de carácter irónico. En primer lugar, desdramatiza la idea de que estamos viviendo una realidad apocalíptica. Aludiendo a la experiencia del escritor de ciencia ficción James Graham Ballard en un campamento de prisioneros de guerra en el Shanghái de la década de 1940, el filósofo británico trata de persuadirnos sobre la capacidad de resiliencia del "animal humano". Según el británico: "Lo que se suele calificar de apocalipsis es el curso normal de la historia” (Gray, 2020, 12 de abril). Si la ciencia nos ayudará a defendernos del virus, la tecnología nos servirá para adaptarnos a las condiciones extremas que vivimos. A diferencia de Agamben, Gray parece regocijarse con el mundo que se avecina: "Es posible que mucha gente migre a entornos en la Red, como en Second Life, un mundo virtual en el que las personas se conocen, comercian e interactúan en el cuerpo y el mundo que ellas eligen" (2020, 12 de abril). Pero el ciberespacio depende de infraestructuras que pueden ser dañadas o destruidas por una guerra o una catástrofe natural. Y es que, como reconoce el filósofo, "Internet nos sirve para evitar el aislamiento que acompañó a las epidemias en el pasado, pero no permite que los seres humanos escapemos de nuestra carne mortal ni que esquivemos las ironías del progreso" (Gray, 2020, 12 de abril).

Las conclusiones de Gray no pueden ser más claras. El virus nos enseña no sólo el carácter reversible del progreso, sino sus propios pies de barro. "La desglobalización en marcha es hija de la globalización”, remacha este crítico liberal del liberalismo. El filósofo insiste en su idea de que son los Estados nacionales los que saldrán reforzados de la crisis, pues están mejor preparados para "conducir la acción a gran escala". La idea de un crecimiento indefinido es tan insostenible como el desprecio liberal o socialista de la identidad nacional. Para Gray: "En esencia, el Estado británico siempre ha sido hobbesiano. La paz y un Gobierno fuerte 
han sido sus prioridades fundamentales. Al mismo tiempo, este Estado hobbesiano ha descansado sobre el consentimiento, sobre todo en épocas de emergencia nacional. La protección contra el peligro se ha impuesto a la libertad frente a las injerencias del Gobierno" (2020, 12 de abril).

Gray deja abierta la cuestión sobre qué parte de nuestra libertad estaremos dispuestos a recuperar una vez superado el pico de la pandemia. Pero lo que tiene claro este autor es que la solidaridad socialista no será un plato de gusto para los británicos, si bien quizá vean con buenos ojos lo que Agamben y Han tanto temen, es decir, "un régimen de biovigilancia en aras de una mayor protección de su salud". Lo que necesitamos, según el filósofo, es más intervención estatal, pero una intervención creativa que ofrezca respaldo a la investigación científica y a la innovación tecnológica. Aunque pueda resultar intrusivo según los criterios del viejo mundo, para Gray, “el gobierno posliberal será la norma en el futuro próximo”.

La tesis de Gray es que el liberalismo debe reconocer sus errores si quiere preservar sus valores más esenciales. Y su principal error ha sido desconocer la importancia psicológica de la seguridad y la pertenencia, las cuales tienen tanto predicamento para las personas como la libertad individual. Es por ello que el filósofo británico considera el confinamiento como una magnífica oportunidad para renovar nuestras ideas y pensar cómo vivir en un mundo alterado.

\section{Confianza en el estado y salida de la caverna: Villacañas y Lledó}

Los filósofos españoles también se han lanzado a pensar la crisis del coronavirus. ${ }^{5}$ El 2 de marzo, José Luis Villacañas publicaba en

${ }^{5}$ Véase también, entre otras contribuciones hispanas, Innerarity (2020); Savater, 
El Mercantil Valenciano un texto titulado significativamente "Supervivencia". En él, este profesor de la Universidad Complutense trata de responder a la pregunta de Amelia Valcárcel sobre si la condición apocalíptica del presente es real o retórica.

Las consideraciones de Villacañas parten de un análisis de los artículos anteriormente comentados de Agamben y Nancy. El texto de Agamben al que se refiere nuestro autor es el primero que publicaba el italiano titulado "La invención de una epidemia". Como se recordará, en aquel artículo del 26 de febrero, Agamben expresaba su indignación ante las medidas restrictivas tomadas por su gobierno para parar el contagio del coronavirus. Su tesis era que se estaba aprovechando la crisis para instaurar un estado de excepción como forma normal de gobierno. Según Villacañas, para Agamben, el apocalipsis sería pura retórica.

El filósofo español trata de rebatir a su colega italiano mediante argumentos antropológicos. La condición apocalíptica no tiene tanto que ver con una retórica apocalíptica de carácter estatal, como con determinados fenómenos de escalada y aceleración que determinan en la población una sensibilidad hiperestésica, es decir, exagerada. Desde este punto de vista, la propia excepcionalidad, según Villacañas, "será también un fenómeno de escalada y de aceleración, y en su torbellino todo estará permitido para garantizar la supervivencia” (2020, 2 de marzo).

Los procesos de escalada apocalíptica no son puestos en marcha por el poder, sino que se fundamentan en "la aspiración de la mente humana a la prevención”. Es el deseo de seguridad el que demanda que el soberano decida sobre el estado de excepción. Por el contrario, prosigue Villacañas, “Agamben, que en su filosofía ha abordado el concepto de ser humano evadiendo estos hechos elementales, tiene que situar todos estos fenómenos en el poder del

(2020, 3 de abril); Gomá (2020, 8 de noviembre); Marín-Casanova (2020a y 2020b), etc. 
Estado" (2020, 2 de marzo). No soportaríamos el poder del Estado si éste careciese de toda base antropológica.

La respuesta de Jean-Luc Nancy a "su viejo amigo Agamben", según el profesor Villacañas, iría en esa dirección. Cuando Nancy le recuerda a Agamben que, de haber seguido su consejo de no hacerse un trasplante de corazón, él ahora probablemente estaría muerto, tras el argumento ad hominem, se esconde la verdad de un deseo que, más allá de las sutilezas de la filosofía, converge con la necesidad humana de supervivencia. La condición apocalíptica de la excepcionalidad no responde a ninguna retórica, sino al estado normal real en que vive hoy la propia humanidad.

Así como Nancy cree que se está poniendo en duda toda una civilización, Villacañas piensa que los fenómenos de escalada y aceleración como los que hoy vivimos nos inducen a pensar que "estamos ante un atolladero evolutivo". La diferencia con otras épocas apocalípticas es que si antes el ser humano sólo presentía el atolladero, ahora lo conocemos. El filósofo español concluye su artículo expresando su confianza en el Estado ante la certeza de que el capitalismo sabrá aprovecharse de las catástrofes que vengan.

El 9 de marzo, en un segundo artículo titulado "Cuarentena mental", Villacañas reflexionaba en el mismo medio sobre una antigua verdad que la "omnipotencia de lo real" ha puesto de manifiesto: la verdad de la improbabilidad de nuestra existencia. El profesor utiliza el término numinoso, tomado de la filosofía de la religión, para referirse al "poder anónimo" que nos amenaza, un poder desconocido que quizá hubiera sido mejor caracterizar como "inquietante", en alemán unheimlich. Sin embargo, el filósofo no se muestra inquieto. El mundo humano, hecho a nuestra medida, ha ocultado siempre en su seno el poder de lo primigenio. El hombre se descubre de pronto como un cazador cazado.

Las amargas verdades de nuestros clásicos, demasiado pronto olvidadas, cobran una inesperada actualidad. ¿Dónde quedan 
nuestras abstractas ideas filosóficas? No parece tiempo para filosofías, sino para el trabajo consolador del mito. Villacañas evoca a nuestro Jorge Manrique, el poeta del tópico Ubi sunt?, ¿dónde están? En efecto, ¿dónde quedan todas esas teorías sobre el hombre económico o el valor absoluto de la economía? "Lo que nos decimos para calmar el aburrimiento que nos produce una adaptación demasiado lograda, se viene abajo en un instante, tan pronto nos damos cuenta de que esa adaptación nunca es del todo estable y que en cualquier recodo nos espera el regreso a la situación originaria de indefensión” (Villacañas, 2020, 9 de marzo).

¿Extraeremos alguna lección del coronavirus? El filósofo español cree que sí: "Que nos haya conmovido el problema del coronavirus al menos ha puesto de manifiesto esto: que sólo nos contentamos con algo que sea significativo para la humanidad entera. Ninguna lección, pregunta o señal que sirva para algunos, para una localidad, para una nación” (Villacañas, 2020, 9 de marzo), sentencia el filósofo. La humanidad constituye una familia, una familia hermanada en la vulnerabilidad de su destino común. Villacañas concluye: “¿Queremos una lección? Nadie podrá separarnos de lo común básico de la vida ni podrá hacer de la vida una realidad ajena por completo a la amenaza de la entropía. La conciencia de la fragilidad de la vida, eso es lo que compartimos” (2020, 9 de marzo).

De pronto se ha parado todo, casi en seco. ¿Pero no existían indicios suficientes para darnos cuenta de la insostenibilidad de nuestro ritmo frenético de vida? La verdad es que así era, pero no ha sido la inteligencia humana la que lo ha revelado, sino "la estructura más arcaica de la vida”. La naturaleza nos enseña lo que nosotros no somos capaces de aprender a pesar del poder de nuestra tecnología. Necesitábamos un alto en el camino, la paradoja dolorosa es que haya sido la naturaleza, no la cultura, la que mandó parar. 
Pero tras el alto en el camino, ¿no corremos acaso el riesgo de seguir viviendo como si nada hubiera pasado? Al igual que Žižek o Gabriel, Villacañas no nos lo aconseja: "Un alto en el camino y una reflexión, eso podría ser útil. Y preguntarnos si podemos seguir en los procesos en los que estamos embarcados. Esos procesos tienen un nombre general: acumulación indefinida. Ahora también comprendemos que hemos ido acumulando malestar en la misma proporción y quizá debiéramos comenzar a compensar esto” (2020, 9 de marzo). Estamos cansados, cansados de no saber a dónde vamos acumulando tanto, consumiendo como si no existiera un mañana. Las últimas preguntas de José Luis Villacañas constituyen una invitación a cambiar nuestro modelo de vida: “ ¿Y si salvaguardar la comunidad de la vida exigiera no acumular, sino precisamente gastar la riqueza acumulada en la investigación, en la protección general? ¿Y si este tipo de experiencias dramáticas nos diera la señal de que no hay posibilidad de salvarse solos? ¿Y si dejamos de pensar el sistema productivo al servicio de su propia acumulación indefinida y lo encaminamos a objetivos sociales equilibrados y lo pensamos capaz de aceptar sus propios límites?” (2020, 9 de marzo).

El 23 de marzo, José Luis Villacañas publicaba un tercer artículo titulado "El filósofo democrático". El profesor español se muestra irónico ante los reproches lanzados en las redes a los filósofos a raíz de la crisis del coronavirus. Para Villacañas, lo que piensa un filósofo en la soledad de su rincón, suele encontrarse en contradicción con la "experiencia general" y el "sentido común", pues en su soberbia los pensadores creen que la realidad ha de darles siempre la razón. Pero Villacañas piensa que no se debe confundir el pensamiento con la realidad.

No hay que culpar a la filosofía de la actual confusión, si acaso a las ciencias sociales, pues son ellas las que deberían emitir un mejor diagnóstico. Según Villacañas, "el filósofo no tiene otras 
evidencias que las que están al alcance de los demás ciudadanos. Comparte el mundo con ellos. No tiene mundo propio. No ve más lejos ni diagnostica mejor" (2020, 23 de marzo). Por consiguiente, su misión será asumir, por lo pronto, la "condición democrática de su oficio" y no aventurarse en diagnósticos precipitados. Ante todo, lo que el filósofo debe evitar es que la gente siga a los malos filósofos.

El lema de Husserl, "a las cosas mismas", se convierte en boca del autor de Imperiofilia y el populismo nacional-católico en un ideal de atención para el filósofo democrático. Atenerse a la realidad significa en la actual coyuntura evitar toda precipitación y, sobre todo, no creer que el mundo debe ser como nosotros pensamos. Pues el mundo, sentencia Villacañas citando un aforismo de Kafka, no dejará de manifestarse ante nuestra expectante mirada. Por lo demás, el filósofo español no cree que esta crisis vaya a sacar lo mejor y lo peor de nosotros mismos. Simplemente, "nos va a sacar a nosotros mismos".

El filósofo democrático no se erige en guía de una humanidad sin rumbo: le basta con no engañarse y no ser utilizado. Lo que es seguro es que nada será mejor cuando la pandemia pase. Si Han pensaba que el virus por sí mismo no traerá la revolución, Villacañas afirma que las catástrofes no mejoran necesariamente el sentido de la ciudadanía. Al contrario: todas las pandemias han sido recibidas "con gritos y voces, cuando no con chivos expiatorios". Dos tópicos han sido aquí sometidos a la crítica del filósofo: no seremos mejores ni peores, y por añadidura, nada será mejor después del coronavirus.

Frente al oportunismo de los que alzan la voz, la filosofía se limitará a extraer pequeñas enseñanzas de la experiencia. En relación a la crisis de la Covid-19, las preguntas que se hace Villacañas como filósofo democrático son más bien prosaicas: “¿Cuántas camas plenamente equipadas debe tener un país como el 
nuestro? ¿Cuántas mascarillas quirúrgicas debemos disponer en reserva? ¿Cuántos médicos en activo deben existir por miles de ciudadanos? ¿Cómo mantener a los médicos jubilados encuadrados en servicios de emergencia? ¿Qué teletrabajos podemos establecer para un caso de necesidad? ¿Cómo podemos mantener condiciones de vida de mínima dignidad para que no haya sufrimiento añadido en una desgracia semejante?” (2020, 23 de marzo).

El 28 de marzo el diario El País realizaba una entrevista sobre la crisis del coronavirus al gran filósofo español Emilio Lledó. Confinado en su piso de Madrid, Lledó halla consuelo en los clásicos en medio de un caos que dice no alcanzar a comprender. Estamos ante una situación "inexperimentada”, palabra inédita para una realidad también inédita. El filósofo, que vivió de niño la Guerra Civil española, no parece aceptar la adopción del lenguaje bélico para definir la crisis: “¿pero esto, qué es esto, dónde está aquí la violencia, qué es esta tranquilidad silenciosa que nos amenaza, ese peligro que no se oye, dónde está ese virus inodoro, incoloro e insípido?” (Lledó, 2020, 28 de marzo).

Don Emilio, que no quiere ser moralista, piensa que esta crisis es una magnífica oportunidad para salir de la caverna de Platón. El cultivo de la inteligencia crítica se revela aquí indispensable. Como el prisionero de la caverna, ante el coronavirus podemos preguntarnos: “quién nos dice la verdad, quién nos engaña, quién quiere manipularnos”. Sin embargo, el profesor Lledó no oculta su temor de que el virus acabe obviando otras pandemias no menos graves como "el deterioro de la educación, de la cultura y del conocimiento".

El filósofo español, miembro desde 1993 de la Real Academia Española, insiste en la importancia de lo público para afrontar la actual situación, recordándonos la idea de Aristóteles según la cual la política no es más que la búsqueda del bien común. Y si bien reconoce que el virus nos confronta con la muerte, Lledó cree que 
no debemos temerla, pues los ideales son inmortales, en realidad la única forma de continuidad que nos es dada a los humanos.

El virus no nos vencerá, asiente el filósofo sevillano a su entrevistador, aunque añade: "Pero debemos estar alerta para que nadie se aproveche de lo vírico para seguir manteniéndonos en la oscuridad y extender más la indecencia. Sobrecoge ver el poder que tienen sobre nosotros ciertas personas disparatadas, pues un imbécil con poder es algo terrible. Deseo de verdad que esto nos sirva para algo como sociedad. Que propicie un nuevo encuentro con los otros en la polis, en la vida en común” (Lledó, 2020, 28 de marzo).

\section{Conclusiones}

Podríamos seguir recopilando opiniones filosóficas sobre la crisis del coronavirus, pero las seleccionadas son suficientes para realizar un balance crítico y aventurar, por nuestra parte, algunas reflexiones. No menos que económica o sanitaria, la crisis del coronavirus tiene una dimensión ontológica, epistemológica, retórica, ética, política, antropológica. En definitiva, todas las áreas canónicas de la filosofía se ven “aguijoneadas” por la aparición de la pandemia, la cual es probable que signifique para el imaginario colectivo del siglo XXI lo que el terremoto de Lisboa supuso para los filósofos del siglo XVIII o el hundimiento del Titanic para la sociedad occidental del siglo XX.

Cuando parecía que lo virtual era ya nuestro mundo, resulta que un virus viene a recordarnos que existe eso que se llama "realidad", entendiendo aquí por realidad, por lo pronto, el llamado "mundo externo", la res extensa cartesiana o el mundo 1 popperiano, aunque sería más exacto decir que el mundo que ha sido redescubierto es el "mundo invisible" que el microscopio puso de manifiesto en el primer decenio del siglo XVII. Puede que la 
pandemia no nos obligue a preguntarnos “¿por qué es el ser y no más bien la nada?”, la pregunta fundamental de la metafísica según Heidegger, pero que la crisis nos aboca a la ontología, eso parece indudable. José Luis Villacañas, por ejemplo, afirma en su artículo “Cuarentena mental” que es la “omnipotencia de lo real” la que nos ha puesto de cara a la verdad de nuestro ser contingente. El filósofo español saca de aquí una consecuencia importante, si bien la expresa en otro artículo titulado "El filósofo democrático": no se debe confundir el pensamiento con la realidad. Pues si muchos filósofos se equivocan en el diagnóstico de la situación epidémica, por emplear la expresión de Badiou, es justamente porque se obstinan en hacer coincidir los acontecimientos con el pensamiento que han elaborado laboriosamente durante años. El constructivismo, la idea según la cual la realidad sólo es un artefacto humano, parece quedar cuando menos en entredicho. El virus más bien evidencia lo que el filósofo alemán Hans Blumenberg llama el "absolutismo de la realidad” (Blumenberg, 2003).

Byun-Chul Han también se ha referido a la dimensión metafísica de esta crisis. En su artículo nos habla de cómo la digitalización de la sociedad había eliminado prácticamente la resistencia que ofrece la realidad, un concepto que no es original, pues se encuentra, entre otros, en el realismo volitivo de Maine de Biran y de Dilthey. Pero lo real se nos presenta de pronto bajo la forma de un agente patógeno desconocido. Es como si descubriéramos que existe "el afuera”, un afuera de nosotros mismos y de los mundos que habitábamos alienados en el entorno digital. La omnipotencia del principio del placer, por decirlo con un término de Freud, virtualmente irresistible, vuelve a encontrarse con la resistencia negativa del principio de realidad. Cuando Han habla de un exceso de positividad en la sociedad se está refiriendo, sin duda, a una categoría ontológica que se ve inesperadamente enfrentada a la 
negatividad real que representa el propio virus. Y cuando Emilio Lledó se refiere al coronavirus como una situación "inexperimentada", mienta una realidad para la que no tenemos, ciertamente, un nombre.

Markus Gabriel, por su parte, también está de acuerdo respecto a la pertinencia de la metafísica para pensar el coronavirus. Según el alemán, para quien ingenuamente sólo saldremos de la crisis mediante una "pandemia metafísica", los virus plantean un problema metafísico. ¿Por qué? Pues porque no sabemos si son seres vivos. No sabemos qué son los virus y eso nos enfrenta con un problema que no sólo compete a la biología, sino a la ontología, e incluso a lo que podríamos llamar, también con Freud, psicología de las masas, pues el miedo proviene siempre del miedo a lo desconocido. Pero quizá sea éste un problema menor en comparación con la tremenda revelación ontológica de la Covid-19: la realidad existe y el hombre, como diría Zubiri, está religado a ella por más que quiera abolirla para hacer un mundo a su medida.

Quisiera, antes de terminar con la dimensión metafísica del problema, aducir un concepto ontológico del que ninguno de los pensadores comparados en este trabajo ha dicho la más mínima palabra. Me refiero al concepto de "acontecimiento". ¿Supone el coronavirus un "acontecimiento" o no deja de ser un "simulacro" más absorbido por la sociedad del espectáculo? (Baudrillard, 2007; Debord, 2000). Aunque sólo sea por la inquietud que está despertando el fenómeno como revulsivo del pensamiento, el virus mereciera inscribirse en la categoría del acontecimiento.

Resulta extraño, sin embargo, que pensadores que han escrito sobre el tema y que incluso han titulado algunos de sus libros utilizando el concepto, me refiero a Žižek y a Badiou, no se hayan referido en sus artículos a la aparición del coronavirus como un acontecimiento. Esta ausencia debiera ya hacernos pensar sobre la relevancia filosófica de la crisis vírica. ¿Pero qué es un 
acontecimiento? Según Žižek, un acontecimiento es “algo traumático, perturbador, que parece suceder de repente y que interrumpe el curso normal de las cosas; algo que surge aparentemente de la nada, sin causas discernibles, una apariencia que no tiene como base nada sólido” (2014, p. 16). Después de un acontecimiento nada puede volver a ser igual. ¿Por qué una epidemia no puede suponer un acontecimiento? ¿Acaso no se repite por activa y por pasiva que nada va a volver a ser igual cuando pase la crisis del coronavirus?

Si Žižek no aclara, al menos en sus artículos, si la pandemia supone un acontecimiento en los términos en que él mismo ha definido esta noción capital de la filosofía contemporánea, Badiou niega que el coronavirus constituya un evento inédito del que quepa esperar un cambio radical en el proceso de la historia, una posición que difiere sustancialmente del análisis de John Gray y, en parte, de las consideraciones del historiador Yuval Noah Harari. En un análisis sumamente duro y realista, el filósofo francés se niega a ver en la epidemia un acontecimiento "políticamente innovador" y atribuye la confusión reinante, sobre todo en los medios de comunicación de masas, a la incapacidad para reconocer la "ausencia de novedad" que supone esta crisis sanitaria. ¿Podría constituir la situación epidémica la ocasión propicia para el aparecer imprevisible de un nuevo sujeto político en la historia? Según Badiou, "lo que adviene, el suplemento puro, es incalculable y desconocido, es lo que «ha surgido de la grupa y del brinco»" (cit. en Leveque, 2011, p. 84). ${ }^{6}$ Pero es evidente, según este autor, que el coronavirus no ha irrumpido en nuestra situación como un acontecimiento imposible en relación a la legalidad de nuestro mundo.

Desde el punto de vista epistemológico, este virus también nos desafía con preguntas ciertamente incómodas. Dejando aparte el

\footnotetext{
${ }^{6}$ Véase también Badiou (1999).
} 
hecho de que desconocemos qué son los virus, en general, y cuál es la naturaleza del coronavirus, en particular, cuestiones en principio "científicas", la crisis actual nos confronta con problemas relacionados con la veracidad de la información y la llamada posverdad (Ferraris, 2019). Por ejemplo, Žižek se pregunta con razón en "Un claro elemento de histeria racista en el nuevo coronavirus": “¿dónde terminan los hechos y dónde comienza la ideología?” Pero para un mundo que ha hecho de la hermenéutica su particular koiné filosófica, por utilizar la feliz expresión de Gianni Vattimo, no parece que la llamada a las cosas mismas, que no se deberían confundir con los hechos del positivismo, un guiño de Villacañas al viejo Husserl, vaya a surtir ningún efecto a corto o medio plazo.

Ante la amenaza de confusión, no es extraño que filósofos como Žižek o Badiou se muestren críticos con las redes sociales y apelen a la ciencia para saber orientarnos en la presente situación. La ciencia se reivindica, una vez más, como paradigma de conocimiento. Incluso Villacañas afirma que son las ciencias sociales, y no la filosofía, las que tienen la tarea de ofrecer un mejor diagnóstico sobre la crisis. Sólo Gabriel, y en especial Agamben, parecen mostrar en este punto sus reservas. En efecto, para la joven promesa germana el conocimiento científico es insuficiente no ya para vencer el virus, sino para superar un orden mundial letal respecto del cual el coronavirus quizá no sea más que un fenómeno concomitante. Y el autor de La comunidad que viene ha llegado a afirmar en una reciente entrevista que la ciencia es nada menos que la religión de nuestro tiempo (2020, 26 de mayo).

Villacañas, a su vez, hastiado de los castillos de naipes conceptuales levantados por sus colegas, apela a la "experiencia general" y al "sentido común" para hacernos cargo de una situación que nos desborda a todos, incluido el filósofo. La pregunta por el saber sigue, no obstante, en pie, como así lo demuestran, por un 
lado, la incertidumbre de Žižek sobre el "mecanismo preciso" del virus”, y por otro, las desazonadas preguntas del profesor Lledó: "quién nos dice la verdad, quién nos engaña, quién quiere manipularnos".

El coronavirus constituye también un problema para la filosofía del lenguaje y la retórica. Pensemos, por ejemplo, como nos recuerdan Žižek y Horvat, en la connotación racista o ideológica de la expresión "virus chino" con la que Trump se refería al coronavirus. Con la palabra humanizamos lo no humano, pero no siempre lo hacemos con la mejor intención. Por ejemplo, ¿es el lenguaje bélico sólo una metáfora inocente para ilustrar la situación o describe fielmente la realidad? Si Agamben, Badiou y Chomsky consideran pertinente semejante lenguaje, Lledó, que vivió la guerra civil, muestra su perplejidad: “¿dónde está aquí la violencia, qué es esta tranquilidad silenciosa que nos amenaza, ese peligro que no se oye, dónde está ese virus inodoro, incoloro e insípido?” (2020, 28 de marzo), pregunta el que fuera profesor de la Universidad de Barcelona.

Agamben y Badiou no están, sin embargo, de acuerdo con el uso belicista del lenguaje por las mismas razones. En efecto, si para el italiano el lenguaje bélico es la consecuencia de un estado de emergencia decretado injustificadamente por el estado, para el francés, quien equipara epidemia y guerra, la retórica bélica se corresponde perfectamente con un proceso mortal donde se entrecruzan la naturaleza (virus) y la sociedad (Estado nacional). Si hubiera que hablar de guerra, se trataría de una guerra civil, la más absurda de las guerras, en la que el enemigo está ahora en nuestro propio interior, sostiene Agamben, cuyo punto de vista no puede estar más alejado del de Badiou.

Junto a la metafórica bélica podríamos hablar aquí de la metáfora biológica de la inmunidad. ¿ Nos encontramos en plena época inmunológica? El pensador que sale aquí a relucir, sin duda, 
es Esposito, pero también Han, cuya tesis de la sustitución de la época viral por una época neuronal se ha visto con la aparición de la pandemia seriamente comprometida. En un artículo traducido al castellano como "Biopolítica y coronavirus", Esposito mencionaba las "prácticas profilácticas" que están poniendo en evidencia tanto "el síndrome inmune real" del nuevo régimen biopolítico como la fortaleza misma del sistema inmunitario de la sociedad. El autor de Inmunitas se había referido de hecho en esta obra a la lucha contra un brote epidémico como un acontecimiento, entre otros, que debe entenderse como una respuesta de protección ante un peligro (Esposito, 2005, p. 9). Otros fenómenos que prueban la vigencia del paradigma inmunológico para entender nuestro mundo serían la lucha contra la inmigración ilegal o las medidas para neutralizar el último virus informático.

Pues bien, en su ensayo de 2010, La sociedad del cansancio, Han consideraba que Esposito basaba su afirmación en un falso supuesto. En su opinión, "el paradigma inmunológico no es compatible con el proceso de globalización” (Han, 2019a, p. 18). La otredad inmunológica habría sido sustituida por la diferencia posmoderna, la cual “ya no genera ninguna enfermedad”. ¿Cómo explicar entonces la fuerte reacción inmunológica que ha suscitado el coronavirus? Han no piensa que el pánico pandémico suponga una refutación de su tesis sobre la obsolescencia del paradigma inmunológico, sino precisamente la confirmación de que nos habíamos acostumbrado a vivir en un mundo sin graves amenazas exteriores. "La reacción inmunitaria es tan violenta", escribe en su artículo, "porque hemos vivido durante mucho tiempo en una sociedad sin enemigos, en una sociedad de la positividad, y ahora el virus se percibe como un terror permanente" (Han, 2020, 22 de marzo). Se percibe, lo cual no significa que lo sea.

Ante esta ingeniosa salida ad hoc, Žižek, en una entrevista concedida al diario El Mundo, no puede por menos que responder 
al surcoreano: "Han dice que los países occidentales están reaccionando de forma exagerada porque se estaban acostumbrando a vivir sin enemigos abiertos y tolerantes, sin mecanismos de inmunidad, por lo que cuando surgió una amenaza real entraron en pánico. ¿De verdad? ¿No está todo nuestro espectro político y social impregnado de visiones apocalípticas, amenazas de catástrofe ecológica, miedo a los refugiados musulmanes, defensa del pánico de nuestra cultura tradicional contra el universo LGBT y la teoría de género?” (2020, 27 de marzo).

Relacionado con esta temática se halla cierta retórica apocalíptica que prolifera sobre todo en las redes sociales. Amelia Valcárcel le preguntaba en un encuentro a José Luis Villacañas si el apocalipsis en relación al coronavirus es real o meramente retórico. Villacañas le contesta, como tuvimos oportunidad de comprobar, remitiéndole a los primeros artículos de Giorgio Agamben y Jean-Luc Nancy. Para el primero es evidente que el apocalipsis es una retórica de la que se sirven los gobiernos para decretar el estado de excepción. Sin embargo, para el segundo, la aceleración excepcional, propia del apocalipsis, sería la realidad en la que vive ya inmersa la humanidad, como por otro lado reconoce el mismo Harari al afirmar que no son estos tiempos normales. Realidad con la que parece coincidir Villacañas al ver la crisis presente como un fenómeno histórico, para nada retórico, de escalada y aceleración, una idea que se encuentra en los teóricos de la aceleración de la historia y con la que Gray se muestra de acuerdo cuando afirma sin ningún tipo de pathos que "lo que se suele calificar de apocalipsis es el curso normal de la historia”. Lo que no ven Nancy ni Villacañas es que la tesis de la excepcionalidad, devenida norma de nuestro mundo, acaba dando la razón indirectamente a la tesis agambeniana de un estado de excepción permanente. Y es que más allá de que éste sea producto 
de una decisión soberana o de una aceleración puntual de carácter histórico, lo cierto es que al final la normalidad de la crisis acaba confirmando la regla del propio estado de excepción. ${ }^{7}$

Pero si hay un campo de reflexión que no podía quedar indemne con el coronavirus ése no es otro que el de la ética. Pensemos, por ejemplo, en la expresión "moral de victoria" utilizada por el presidente Pedro Sánchez como requisito indispensable para vencer el virus. Si dejamos al lado por un momento los dilemas bioéticos que se plantean los sanitarios a la hora de tener que decidir a quién salvar en caso de necesidad, podemos afirmar que la mayoría de los autores de los que aquí nos hemos ocupado, a excepción quizá de Gray, están de acuerdo en afirmar que del virus tiene que extraerse inevitablemente una lección moral. Es el caso de Žižek cuando, más allá de su extemporánea llamada a un nuevo comunismo, sostiene que necesitamos "una solidaridad incondicional total y una respuesta coordinada globalmente", ${ }^{8}$ pues no podemos seguir viviendo como de costumbre. Solidaridad, cooperación, fraternidad, unidad... aparecen como los nuevos mantras del neomoralismo que el virus ha liberado entre los filósofos.

Si existe un pensador con sensibilidad ética entre los citados en el elenco que hemos seleccionado ése no es otro que Giorgio Agamben. A pesar de la precipitación de su juicio, calificando el coronavirus como una "gripe normal", el filósofo italiano ha detectado como ningún otro, con excepción de su compatriota Nuccio Ordine, las consecuencias morales del confinamiento. "El otro ha sido abolido", afirma con contundencia el gran pensador, o

\footnotetext{
7 "La gente habla sobre cuándo se volverá a la normalidad, pero la normalidad era la crisis” (cit. en Moreno, 2020, 1 de abril), comenta con extraordinaria lucidez Naomi Klein en un encuentro virtual el pasado 26 de marzo.

${ }^{8}$ La mejor expresión de la interdependencia mutua que el coronavirus ha puesto de manifiesto es, sin duda, la de Morin: "El virus nos dice entonces que esta interdependencia debe dar lugar a la solidaridad humana en la conciencia de nuestro destino común” (2020, 13 de marzo).
} 
es construido ideológicamente en tanto enfermedad, una interesante idea de Horvat de la que Agamben no se encuentra muy alejado. Lo relevante de este diagnóstico es que de nada servirían aquí las llamadas a la solidaridad y la cooperación internacional cuando se nos priva de la condición de posibilidad de las mismas: la comunidad. La referencia a la figura del untore, el untador, en su texto titulado "Contagio" es enormemente significativa. El miedo al otro, un tema en el que insiste también el croata Horvat, se generaliza. Es más: la mentalidad policial inducida al ciudadano, temida por el mediático filósofo y docente argentino Darío Sztajnszrajber, conduce a criminalizar al sospechoso de estar contagiado. René Girard habría dicho seguramente que convertimos al otro en un chivo expiatorio, una víctima inocente como salida a la crisis de la comunidad (Girard, 1986).

El hombre es un ser que valora, un animal axiológico. Cuando Agamben dice, por lo demás, que a los italianos no parece importarles otra cosa que la mera supervivencia, apunta a una cuestión que es indudablemente ética. ¿Cuál es nuestra escala de valores? ¿La libertad, la seguridad, acaso la igualdad? ¡No! Nuestro valor hoy por hoy no es otro que la salud, o por decirlo con Agamben, la vida desnuda. Y es que como reconoce Harari en un artículo publicado originalmente por Financial Times, si a la gente se le da a elegir entre salud o intimidad prefiere siempre la preservación de su salud (2020, 5 de abril). Pero cuando estamos dispuestos a sacrificar todo por la vida, postula el autor de Homo sacer, la vida política deja de ser una vida cualificada para identificarse con el mero hecho de vivir, común a todos los animales. La vida nuda no es más que vida nula. Pero, como ya sabía el viejo Aristóteles, "los hombres no han formado una comunidad sólo para vivir, sino para vivir bien”.

Han no cree que el virus nos vaya a cambiar. El virus nos aísla como seres humanos. El cambio sólo puede provenir de la razón, 
afirma sin redefinir un concepto que ya no nos dice nada. Gabriel, por su parte, insiste también en la dimensión moral de la crisis del coronavirus. No podemos seguir actuando como antes, eso está claro, pero si queremos cambiar necesitamos de una "educación ética” que contrarreste la superstición de que la ciencia y la técnica pueden resolver por sí mismas nuestros problemas sociales. Por lo demás, si Chomsky hacía un llamamiento a la reconstrucción de los lazos sociales como única salida posible de la crisis (tesis que lo acerca al empoderamiento de la ciudadanía vindicado por Harari), el británico Gray terminaba su artículo con toda una declaración de intenciones según la cual los valores clásicos del liberalismo sólo podrán sobrevivir a la crisis si acabamos reconociendo la importancia de la seguridad y del sentimiento de pertenencia en la psicología de las personas.

Por último, Villacañas y Lledó no han dejado tampoco de valorar los aspectos éticos de la pandemia. El primero, por ejemplo, se ha referido a la necesidad de hacer un alto en el camino y repensar nuestro anterior modo de vida. " $\mathrm{i} Y$ si este tipo de experiencias dramáticas nos diera la señal de que no hay posibilidad de salvarse solos?”, pregunta Villacañas. Pero el filósofo se muestra más bien escéptico en su último artículo del 23 de marzo sobre la posibilidad de que el virus nos vaya a hacer mejores. Simplemente, nos mostrará tal y como realmente somos, una idea que comparte con Han y Sztajnszrajber, quien en una entrevista afirma sin complejos: "Ojalá superemos esta pandemia y nos deje algún aprendizaje, pero soy pesimista. Creo que ni bien las cosas vuelvan a la "normalidad" la gente, las empresas y los estados se van a comportar igual que antes" (2020, 29 de marzo).

El ideal ético del filósofo democrático de Villacañas, en definitiva, frente a los filósofos que quisieran que la realidad les diese siempre la razón, no es otro que atenerse a las cosas mismas, evitando cartesianamente la precipitación en el juicio. Un ideal que, 
en cierto modo, comparte Lledó cuando nos insta a permanecer alertas para que nadie se aproveche de lo vírico con la intención de seguir manteniéndonos en la oscuridad y la indecencia.

Pero si hay un tema que el coronavirus replantea es, sin duda, el político. Todos los autores abordan la Covid-19 desde el punto de vista político. Žižek no ve más que una salida de la crisis: la reinvención del comunismo; Horvat ve en el virus un producto del capitalismo global; Agamben considera que el coronavirus no ha servido más que para decretar un estado de excepción injustificado; Esposito cree que la biopolítica es la clave para entender la pandemia; Nancy ve en los estados a tristes ejecutores de una excepcionalidad que se ha convertido en la regla de nuestro mundo; Badiou no hace una lectura política de la situación, si bien afirma que la propagación del virus se debe a la elevación del capitalismo de estado chino a un rango imperial; Han teme la implantación de un estado policial digital en Occidente; Gabriel sostiene que el orden mundial previo al virus era ya letal; Chomsky acusa al neoliberalismo de no haber sabido o querido prevenir la pandemia; Gray afirma que el neoliberalismo ha llegado a su fin y que ha llegado la hora de los estados nacionales; Villacañas confía como filósofo democrático en el estado como nuestra única salvaguarda en una situación de crisis; y Lledó ve en el virus una oportunidad excepcional para salir de la caverna en busca del bien común.

Para Žižek, la alternativa al comunismo sería la barbarie, alternativa que no es ni mucho menos obvia. Han lo critica con razón: "Žižek afirma que el virus ha asestado al capitalismo un golpe mortal, y evoca un oscuro comunismo. Cree incluso que el virus podría hacer caer el régimen chino. Žižek se equivoca” (2020, 22 de marzo). Las palabras de Han suscitaron pronto la reacción del autor de El sublime objeto de la ideología, para quien es evidente que "estamos creando una nueva humanidad unificada". Pero si hay un "oscuro comunismo" evocado en los textos de este debate, ése 
no es el de Žižek, sino el de Badiou cuando se refiere a la necesidad de trabajar durante la cuarentena "en el proyecto de nuevos lugares políticos y en el progreso transnacional de una tercera etapa del comunismo, después de aquella, brillante, de su invención, y de aquella otra, fuerte y compleja, pero finalmente derrotada, de su experimentación estatal” (2020, 22 de marzo). Esa tercera etapa nos hace recordar la edad del espíritu del monje calabrés Joaquín de Fiore, una prueba de que el comunismo como praxis política no puede aspirar hoy a más que a ser una suerte de idea regulativa o principio esperanza.

Más interesante nos parece, en cambio, el debate sobre el estado de excepción y la biopolítica. A pesar de las críticas que ha recibido desde todos los ámbitos, la idea de Agamben sobre la normalidad del estado de excepción no es ni mucho menos descabellada. ${ }^{9}$ No sé en Italia, pero cuando en España el llamado estado de alarma parecía prolongarse sine die y algunos juristas dudaron de la constitucionalidad del mismo, lo mínimo que debe concederse al autor de Estado de excepción es la inquietante verosimilitud de su hipótesis. Creo que aquí Esposito se equivoca al desdeñar el diagnóstico de su compatriota, pues como lo prueba la impresionante obra de Agamben, la tesis de la biopolítica es compatible con el pensamiento del estado de excepción, compatibilidad que podría haber suscitado un diálogo apasionante entre los dos pensadores a propósito del coronavirus. Como dice en el segundo volumen de Homo sacer, la excepción soberana es "el dispositivo original a través del cual el derecho se refiere a la vida y la incluye dentro de sí por medio de la propia suspensión”

9 "El pensamiento de la excepción se confirma con la epidemia, por supuesto; pero también se redimensiona: lo que descubre -con esfuerzo y escándalo, con intenciones dramáticamente subversivas, con inflexiones trágico-apocalípticasel liberalismo ya lo sabe, a su manera, y por necesidad lo práctica, a su manera” (Galli, 2020, 25 de mayo). Este artículo es un magnífico complemento de la tesis de Agamben (2020, 14 de abril). 
(Agamben, 2004, p. 24). Cuando Esposito rechaza el estado de excepción en nombre del paradigma biopolítico parece no darse cuenta de que ambos constituyen un binomio en la tradición política occidental tal y como la interpreta Agamben. En efecto, el "doble proceso de medicalización de la política y politización de la medicina” comentado por el autor de Inmunitas en su artículo es otra manera de dar cuenta de la inclusión de la vida en la política en la que tanto insiste el autor de Homo sacer. Y es que más allá de que esa inclusión sea llevada a cabo o no por un estado de excepción, lo fundamental aquí es que ambos autores coinciden en la diagnosis sobre la intervención del poder en la vida humana. Es más: el mismo estado de excepción puede leerse en realidad como una reacción inmunológica de la sociedad frente a aquello que la amenaza desde dentro, sea justificada o injustificadamente. La diferencia entre los dos es que Agamben no parece encontrar una alternativa al estado de excepción, mientras que Esposito considera que las instituciones democráticas son el verdadero sistema inmunitario de un país ${ }^{10}$.

Pero la biopolítica es tanto o más que un poder sobre la vida, un poder de dar la muerte. La biopolítica es también tanatopolítica o, por decirlo con el filósofo camerunés Achille Mbembe, “necropolítica” (Mbembe, 2003; Fernández Vítores, 2015). Cuando en los hospitales se decide sobre la vida o la muerte de personas, priorizando la de los jóvenes sobre la de los ancianos, la vieja prerrogativa del soberano premoderno, la prerrogativa de dar la muerte, aparece en realidad como un dispositivo complementario de la "administración de los cuerpos" y la "gestión calculadora de la vida” (Foucault, 2006, p. 167). En efecto, el cálculo no se

\footnotetext{
${ }^{10}$ Véase sobre la "democracia inmunitaria” el reciente libro de Di Cesare (2020) donde la autora nos alerta sobre el peligro de que los ciudadanos devengan pacientes de un Estado médico cada vez más propenso a recurrir al estado de excepción.
} 
extiende sólo a la vida, con la reglamentación de los detalles más nimios de nuestra existencia cotidiana, sino que afecta también a la muerte, pues suspende de facto la ley no escrita de Antígona, el derecho de enterramiento, ritual que junto al culto religioso y la institución del matrimonio, constituyen, como sabía Vico, los tres pilares inamovibles de la civilización. Pero cuando cada uno de nosotros se convierte en un potencial portador del virus, el poder de dar la muerte deja de ser una prerrogativa del soberano para pasar a democratizarse, lo cual no significa que la muerte sea democrática, sino que antes bien el poder se encarga de nuevo de administrarla mediante las medidas de confinamiento.

Pero en lo que respecta a la biopolítica, como en su visión del paradigma vírico e inmunológico, Han se equivoca. En su libro Psicopolítica afirma: "La biopolítica es la forma de gobierno de la sociedad disciplinaria. Pero es totalmente inadecuada para el régimen neoliberal que explota principalmente la psique" (Han, 2019b, pp. 37-38). Según el surcoreano, la psicopolitica neoliberal es una forma refinada de explotación mental opuesta a la biopolítica de las sociedades disciplinarias descritas por Foucault. Si el capitalismo moderno se basaba en la fuerza productiva del cuerpo, el neoliberalismo produce, sobre todo, "objetos no-físicos como informaciones y programas”. ${ }^{11}$ Pero, así como la biopolítica es compatible con el estado de excepción, lo es, asimismo, con las técnicas de optimización psíquica de la llamada psicopolítica neoliberal. El coronavirus ha demostrado que lo biológico, somático o corporal, lejos de ser sustituidos por las

${ }^{11}$ Ferraris habla de una "revolución documedial” que habría dejado atrás tanto al capitalismo basado en la producción de mercancías como a la fase medial de la sociedad del espectáculo. "Esta situación cambia con la revolución documedial: la recepción y transmisión se identifican con las redes sociales, y no generan artefactos en relación con la naturaleza ni comunican mensajes efímeros, sino que producen documentos, es decir, objetos sociales que revelan las estructuras que subyacían a las fases anteriores” (2019, p. 83). 
“psicotecnologías”, se convierten en una prioridad para esas mismas técnicas que nos seducen hoy para que seamos nosotros mismos los que disciplinemos y vigilemos nuestros cuerpos y los de los demás. Desde este punto de vita, cabe interpretar más bien la psicopolítica como una forma de gobierno biopolítica. ${ }^{12}$

Por último, podríamos preguntarnos por las consecuencias antropológicas de la crisis del coronavirus. Como si este régimen administrador de la muerte del que hablara Agustín García Calvo nos hiciera olvidar, paradójicamente, nuestra condición mortal, resulta que un virus que no mata a más personas que el tabaco o el alcohol viene a recordar a un Occidente idiotizado el tema fundamental de la antropología filosófica: la consciencia de la muerte. El homo ex machina de la sociedad del espectáculo descubre estupefacto que es un homo mortalis. La contingencia de la existencia humana, como ha revelado Villacañas, queda al desnudo cuando la "omnipotencia de lo real" se despereza ante la humanidad dormida. ¿Pero puede hoy consolarnos la conciencia pascaliana de la mortalidad frente al poder invisible que nos mata? ¿De qué ideales inmortales habla Lledó cuando puedo ser yo mismo el que muere?

Otra idea que no quisiera pasar por alto, y que John Gray ha mencionado como de pasada, pero que es de una importancia antropológica extraordinaria, es que no podemos hablar ya de un mundo de la cultura separado de la naturaleza. Badiou ha demostrado cómo la epidemia nace del entrecruzamiento de naturaleza y cultura. Pero es Gray quien ha sacado la consecuencia filosófica pertinente: la idea de que las pandemias son incidentes pasajeros en la historia nace de "la creencia de que los seres

\footnotetext{
${ }^{12}$ Véase, sin embargo, el interesante punto de vista de Marín-Casanova (2020b), para quien los paradigmas biopolítico y psicopolítico, así como la teoría agambeniana de la excepción, se ven hoy conceptualmente superados por la tecnopolítica.
} 
humanos ya no formamos parte del mundo natural y que podemos crear un ecosistema autónomo, separado del resto de la biosfera" (2020, 12 de abril). La idea de que el mundo humano no forma parte del mundo natural es moderna, pues se remonta al historicismo con sus ramificaciones en el reduccionismo culturalista y constructivista contemporáneo. Pero esta idea no es hoy sostenible. La historia humana vuelve a inscribirse en la historia de la vida y de la Tierra. ${ }^{13} \mathrm{El}$ hombre es un ser bio-cultural, es decir, para entenderlo hay que tener en cuenta tanto los factores naturales como los culturales. Lo cual no significa que tengamos que transigir con esas loas superficiales, producto de una alienación histórica secular, a la Madre Tierra que proliferan hoy a propósito del coronavirus. ${ }^{14} \mathrm{Y}$ es que incluso el mundo virtual de la red, lo que Echeverría llamaba hace bastantes años el "tercer entorno" (Echeverría, 2000) depende de unas infraestructuras, como nos advierte Gray, "que pueden resultar dañadas o destruidas por una guerra o una catástrofe natural”.

${ }^{13}$ Esta inscripción, todo hay que decirlo, se hace a costa de enajenar la idea de la Historia de su lugar propio, que no ha sido históricamente otro que la Historia salutis.

${ }^{14}$ Para muestra, tres botones: "La pandemia es el resultado de la crueldad humana. Intervenimos sin piedad en el ecosistema sensible” (Han, 2020, 12 de mayo). "¿Es el coronavirus una respuesta inmune del planeta a la insolencia del ser humano, que destruye infinitos seres vivos por codicia?” (Gabriel, 2020, 25 de marzo). "Pensemos en la imagen de los delfines que vuelven a Venecia: viene a decir que los humanos son el virus porque se comportan mal, no respetan el medio ambiente, ocupan todo el espacio posible con coches y medios contaminantes” (Klein, 2020, 10 de abril). Estas afirmaciones cursis y ridículas, deudoras lo sepan o no de la controvertida teoría de Gaia de James Lovelock y Lynn Margulis, constituyen un ejemplo de ecologismo acentuadamente crítico con la civilización humana y basado en la dicotomía contrastante naturaleza/cultura. 
A modo de síntesis, podría afirmarse que la crisis del coronavirus nos confronta con las siguientes consecuencias filosóficas:

1) El poder de lo real se impone aparentemente a la supuesta omnipotencia del pensamiento. El "mundo invisible" de los virus demuestra la obviedad de una realidad independiente del hombre que lo descubre, por lo pronto, en su vulnerabilidad esencial (Villacañas).

2) La ciencia y el Big Data se consolidan como paradigmas de conocimiento en la sociedad de la información (Žižek y Han). Pero la sociedad de la información no deja de ser una sociedad del espectáculo que reintroduce la realidad del virus en la hiperrealidad de la lógica baudrillardiana de la simulación, si es que no nos deja sumidos en la perplejidad del absurdo y el sin sentido (Lledó).

3) El lenguaje retórico aparece como un campo de batalla esencial en la esfera de la opinión pública, y así lo demuestra el uso de la metafórica bélica, inmunológica o escatológica -tomada a veces en sentido literal- a la hora de narrar la crisis (Badiou, Esposito, Agamben).

4) La preservación de la salud y la seguridad desplazan a las libertades individuales y al derecho a la intimidad en la escala de valores de la humanidad cuando la vida desnuda se pone en riesgo (Agamben, Gray, Harari). El otro queda abolido (Agamben) o es construido ideológicamente en tanto enfermedad (Horvat), lo cual no obsta para que también descubramos justo ahora la importancia del mismo (Ordine).

5) La biopolítica -en tanto tanatopolítica- se instaura como estado de excepción permanente (Agamben) frente a la alternativa de reforzar las instituciones democráticas para 
controlar la pandemia (Esposito), empoderar a la ciudadanía (Chomsky, Harari) o dar prioridad a la soberanía de los Estados nacionales (Badiou y Gray).

6) El hombre se sorprende a sí mismo como un ser mortal entre naturaleza y cultura en mutua interdependencia cuya historia se inscribe en la historia de la vida y de la Tierra (Morin y Gray).

\section{Referencias}

Agamben, G. (2004). Estado de excepción. Homo sacer II. Trad. Antonio Gimeno Cuspinera. Buenos Aires: Adriana Hidalgo editora.

Agamben, G. (2020, 26 de febrero). "La invención de una epidemia”. https://tinyurl.com/ybte2e7b

Agamben, G. (2020, 11 de marzo). "Contagio”. https://tinyurl.com/yapzk7ua

Agamben, G. (2020, 17 de marzo). “Aclaraciones”. https://tinyurl.com/yd4wkorx

Agamben, G. (2020, 14 de abril). "Una pregunta”. https://tinyurl.com/ybqgswgn

Agamben, G. (2020, 26 de mayo). "La ciencia se ha convertido en la religión de nuestro tiempo”. Entrevistado por Massimiliano Lenzi. https://tinyurl.com/ycgsgpf8

Agamben, G. (2020). A che punto siamo? L'epidemia come politica. Macerata: Quodlibet. [Hay traducción castellana de 2020: ¿En qué punto estamos? La epidemia como política. Buenos Aires: Adriana Hidalgo editora.].

Badiou, A. (1999). El ser y el acontecimiento. Trad. Raúl J. Cerdeiras, Alejandro A. Cerletti y Nilda Prados. Buenos Aires: Manantial. 
Badiou, A. (2020, 22 de marzo). "Sobre la situación epidémica”, traducción de Luis Martínez Andrade. https://tinyurl.com/y9z9eexo Baudrillard, J. (2007). Cultura y simulacro. Trad. Antonio Vicens. Barcelona: Kairós.

Blumenberg, H. (2003). Trabajo sobre el mito. Trad. de Pedro Madrigal. Madrid: Paidós.

Debord, G. (2000). La sociedad del espectáculo. Trad. José Luis Pardo. Valencia: Pre-Textos.

Di Cesare, D. (2020). Virus sovrano? L'asfissia capitalistica. Bollati Boringhieri: Torino [Hay traducción castellana de 2020: ¿Virus soberano? La asfixia capitalista. Trad. de Juan GonzálezCastelao Martínez. Siglo XXI: Madrid.].

Echeverría, J. (2000). Los señores del aire. Telépolis y el tercer entorno. Barcelona: Destino.

Chomsky, N. (2020, 17 de marzo). "Sanità devastata dal neoliberalismo". Entrevistado por Valentina Nicolì. Il Manifesto. https://tinyurl.com/yarhr49q

Chomsky, N. (2020, 28 de marzo). "World After Coronavirus”. Entrevistado por Srećko Horvat. https://tinyurl.com/s3dh73n

Esposito, R. (2005). Inmunitas. Protección y negación de la vida. Trad. de L. Padilla. Buenos Aires: Amorrortu.

Esposito, R. (2020, 12 de marzo). "Cuidados a ultranza". https://tinyurl.com/y7dgt6c5

Esposito, R. (2020, 24 de marzo). "Biopolítica y coronavirus", traducción de Miquel Seguró. https://tinyurl.com/ybutluyu

Esposito, R. (2020, 30 de marzo). "Democracia en tiempo de coronavirus”, traducción de Miquel Seguró. https://tinyurl.com/y7gkm54e

Fernández Vítores, R. (2015). Tanatopolítica. Opúsculo sobre los dispositivos humanos posmodernos. Madrid: Páginas de Espuma. Ferraris, M. (2019). Posverdad y otros enigmas. Trad. Carlos Caranci Sáez. Madrid: Alianza. 
Foucault, M. (2006). Historia de la sexualidad I. La voluntad de saber. Trad. Ulises Guiñaz. Madrid: Siglo XXI.

Foucault, M. (2007). Nacimiento de la biopolítica. Trad. Horacio Pons. México: FCE.

Gabriel, M. (2020, 25 de marzo). "El orden mundial previo al virus era letal”, El País, Babelia. https://tinyurl.com/y9g5cvtz

Girard, R. (1986). El chivo expiatorio. Trad. Joaquín Jordá. Barcelona: Anagrama.

Galli, C. (2020, 25 de mayo). “Epidemia entre norma y excepción”. https://tinyurl.com/y8wygp42

Gomá, J. (2020, 8 de noviembre). “Cuando esta puñetera pandemia pase, recuperaremos esa dulzura de vivir”. Entrevistado por Ixone Díaz Landaluce. Mujerhoy.com https://tinyurl.com/y7of24u6

Gray, J. (2020, 12 de abril). “Adiós a la globalización, comienza un mundo nuevo”, El País. https://tinyurl.com/tkozjc4

Han, B. -Ch. (2019a). La sociedad del cansancio. Trad. Arantzatzu Saratxaga Arregi. Barcelona: Herder.

Han, B. -Ch. (2019b). Psicopolítica. Trad. Alfredo Bergés. Barcelona: Herder.

Han, B. -Ch. (2020, 22 de marzo). "La emergencia viral y el mundo de mañana”, El País, traducción de Alberto Ciria. https://tinyurl.com/wwy2apo

Han, B. -Ch. (2020, 12 de mayo). "Viviremos como en un estado de guerra permanente”. Entrevistado por Carmen Sigüenza y Esther Rebollo. La Vanguardia. https://tinyurl.com/ybb4ea42

Harari, Y. N. (2020, 5 de abril). "El mundo después del coronavirus", traducción de Juan Gabriel López Guix. La Vanguardia. [Actualizado a $06 / 04 / 2020]$. https://tinyurl.com/vp4ofyq

Horvat, S. (2020, 16 de febrero). "Lo más contagioso es el miedo", El País. https://tinyurl.com/ybnh655l 
Innerarity, D. (2020). Pandemocracia. Una filosofía de la crisis del coronavirus. Barcelona: Galaxia Gutenberg.

Kantorowicz, E. H. (2012). Los dos cuerpos del rey. Un estudio de teología política medieval. Trad. Susana Aikin Araluce. Madrid: Akal.

Klein, N. (2020, 10 de abril). "La crisis del coronavirus es una oportunidad para construir otro modelo económico". Entrevistada por Angela Mauro (traducción de Uxía Prieto). Huffpost. https://tinyurl.com/y8g7esrk

Leveque, J. -C. (2011). 'El concepto de 'acontecimiento' en Heidegger, Vattimo y Badiou”, Azafea. Revista de filosofía, 13: 6991.

Lledó, E. (2020, 28 de marzo). “Ojalá el virus nos haga salir de la caverna, la oscuridad y las sombras”. Entrevistado por Pablo de Llano. El País. https://tinyurl.com/u8nv6az

Marín-Casanova, J. A. (2020a). "Consecuencias de una crisis sanitaria. Botiquín de ideas para comprender el coronavirus y su tecno-pandemia informacional”. Revista de Comunicación y Salud, 10(2): 63-80. https://doi.org/10.35669/rcys.2020.10(2).63-80

Marín-Casanova, J. A. (2020b). "Del virus al infovirus. Vistas de la pandemia desde la biopolítica, la teoría de la excepción y la psicopolítica, a la tecnopolítica”. Revista Ethika+, 2: 209-227. https://doi.org/ 10.5354/2452-6037.5848

Mbembe, A. (2003). “Necropolitcs”. Public Culture, 15 (1): 11-40. Moreno, D. (2020, 1 de abril). "Naomi Klein: 'La gente habla sobre cuándo se volverá a la normalidad, pero la normalidad era la crisis'”, El Salto. https://tinyurl.com/trgxfng

Morin, E. (2020, 13 de marzo). "Lo que el coronavirus nos está diciendo". https://tinyurl.com/y9xsrrch

Nancy, J. -L. (2020, 28 de febrero). "Excepción viral”. https://tinyurl.com/y7jd9d8j 
Ordine, N. (2020, 26 de marzo). "La política neoliberal ha descuidado los pilares de la dignidad humana". Entrevistado por Juan Cruz. El País. https://tinyurl.com/rah33dl

Savater, F. (2020, 3 de abril). "No estábamos dispuestos a creer lo que veíamos”. Entrevistado por Pablo Blázquez. Ethic. https://tinyurl.com/vfvs2sn

Schmitt, C. (2009). Teología política. Cuatro capítulos sobre la doctrina de la soberanía. Trad. Francisco Javier Conde y Jorge Navarro Pérez. Madrid: Trotta.

Sloterdijk, P. (2003). Esferas I. Burbujas. Trad. Isidoro Reguera. Madrid: Siruela.

Sloterdijk, P. (2004). Esferas II. Globos. Trad. Isidoro Reguera. Madrid: Siruela.

Sloterdijk, P. (2006). Esferas III. Espumas. Trad. Isidoro Reguera. Madrid: Siruela.

Sontag, S. (1980). La enfermedad y sus metáforas. Trad. Mario Muchnik. Barcelona: Muchnik.

Sztajnszrajber, D. (2020, 29 de marzo). “Ojalá esta pandemia nos deje algún aprendizaje, pero no soy optimista”. Entrevistado por Sebastián Feijoo. Tiempo Argentino. https://tinyurl.com/ycnhppsm Villacañas, J. L. (2020, 2 de marzo). "Supervivencia”, El Mercantil Valenciano. https://tinyurl.com/y7a57up4

Villacañas, J. L. (2020, 9 de marzo). "Cuarentena mental”, El Mercantil Valenciano. https://tinyurl.com/yd3uqn8h Villacañas, J. L. (2020, 23 de marzo). "El filósofo democrático”, El Mercantil Valenciano. https://tinyurl.com/ybcexdas

Žižek, S. (2014). Acontecimiento. Trad. de R. Vicedo. Madrid: Sexto Piso.

Žižek, S. (2020, 8 de marzo). "Un claro elemento de histeria racista en el nuevo coronavirus". https://tinyurl.com/yaohznsw

Žižek, S. (2020, 20 de marzo). "Un golpe tipo 'Kill Bill' al capitalismo”. https://tinyurl.com/y9pjtf5z 
Žižek, S. (2020, 27 de marzo). "Todos somos hoy Julian Assange, encerrados y sin visitas”. Entrevistado por Rebeca Yanke. El Mundo. https://tinyurl.com/ycxg58js

Žižek, S. (2020a). Pan(dem)ic! COVID-19 shakes the world. New York: O/R Books.

Žižek, S. (2020b). Pandemic! 2. Chronicles of a Time Lost. New York: O/R Books. 
